\title{
Immediate and sustained effects of cobalt and zinc-containing pigments on macrophages
}

Julie Devcic ${ }^{1}$, Manon Dussol², Véronique Collin-Faure ${ }^{1}$, Julien Pérard ${ }^{1}$, Daphna Fenel ${ }^{3}$, Guy Schoehn $^{3}$, Marie Carrière ${ }^{2}$, Thierry Rabilloud ${ }^{1 *}$, Bastien Dalzon ${ }^{1 *}$

1 Chemistry and Biology of Metals, Université Grenoble Alpes, CNRS UMR5249, CEA, IRIG-DIESE-LCBM-ProMIT, F-38054 Grenoble

2 Université Grenoble-Alpes, CEA, CNRS, IRIG-DIESE, SyMMES, Chemistry Interface Biology for the Environment, Health and Toxicology (CIBEST)38000 Grenoble, France

3 Univ. Grenoble Alpes, CEA, CNRS, Institut de Biologie Structurale (IBS), Grenoble, France

*: to whom correspondence should be sent: thierry.rabilloud@cnrs.fr or bastien.dalzon@cea.fr

\begin{abstract}
Pigments are among the oldest nanoparticulate products known to mankind, and their use in tattoos is also very old. Nowadays, 25\% American people aged 18 to 50 are tattooed, which poses the question of the delayed effects of tattoos. In this article, we investigated three cobalt (Pigment Violet 14 (purple color)) or cobalt alloy pigments (Pigment Blue 28 (blue color), Pigment Green 14 (green color)), and one zinc pigment (Pigment White 4 (white color)) which constitute a wide range of colors found in tattoos. These pigments contain microparticles and a significant proportion of nanoparticles (in either aggregate or free form). Because of the key role of macrophages in the scavenging of particulate materials, we tested the effects of cobaltand zinc-based pigments on the J774A.1 macrophage cell line. In order to detect delayed effects, we compared two exposure schemes: acute exposure for 24 hours and an exposure for 24 hours followed by a 3-day post-exposure recovery period. The conjunction of these two schemes allowed for the investigation of the delayed or sustained effects of pigments. All pigments induced functional effects on macrophages, most of which were pigment-dependent. For example, Pigment Green 19, Pigment Blue 28, and Pigment White 4 showed a delayed alteration of the phagocytic capacity of cells. Moreover, all the pigments tested induced a slight but significant increase in TNF secretion. This effect, however, was transitory. Conversely, only Pigment Blue 28 induced a short and sustained increase in interleukin 6. Results showed that in response to bacterial stimuli (LPS), the secretion of tumor necrosis factor and interleukin 6 declined after recovery exposure with pigments. The pigments also induced persisting changes in some important macrophage membrane markers such as CD11b, an integrin contributing to cell adhesion and immunological tolerance. In conclusion, the pigments induced functional disorders in macrophages, which, in some cases, persist long after exposure, even at non-toxic doses.
\end{abstract}

Key words: macrophages, cobalt-based pigment, zinc-based pigment, persisting effects, phagocytosis, inflammation. 


\section{Introduction}

Tattooing is an ancient practice which originated in the Stone Age, 6000 years BCE $[1,2]$. It consists in the intradermal injection of non-biodegradable and persistent inks, and historically corresponds to specific medical, cultural, ritual or social roles. Tattoos are not limited to black ink (carbon black) only, and the use of different inks, although increasing recently, go back a long way [3]. Thus, tattoos are generally based on a wide range of colored substances in suspension and these mixtures of substances are not well documented due to insufficient national or international regulations [4]. These pigmentary materials can be composed of various organic (e.g. azo), organometallic (e.g. metal phthalocyanines), or mineral pigments [4] . Tattoos are trending and they increasingly appeal to youngsters. In the USA, 25\% of people aged 18 to 50 are tattooed. In Europe, the prevalence is approximately 10\% [5]. Moreover, tattoos cover a larger surface and tend to be composed of more colors than before. These factors account for the rise in skin injuries, such as dermatosis or neoplasia, reported in the literature $[5,6]$. These short-lived and localized effects (e.g. hypersensitivity skin reactions) are widely known [7]. However, the injection of tattoo inks can also have long-term effects. Indeed, tattooing seems to be the cause of associated with several cases of skin cancer (e.g. melanoma or carcinoma) which incidence appears to be color- or material-dependent. Red inks (composed of azo pigments), for example, increase UV-induced cancers [8]. Black and dark-blue pigments used in tattoos seem to be linked to the majority of post-tattoo skin cancers. These inks may contain impurities which are carcinogenic substances. Carbon black, for example [9] may contain such impurities as polycyclic aromatic hydrocarbons (PAHs) and phenols [10]. Certain inks contain monoazopigments (e.g. yellow or red inks) or heavy metals such as mercury sulfide (red), cadmium (from yellow to red), chromium oxide (green), and cobalt (from purple to green), which are also suspected carcinogens $[9,11,12]$. An excessive quantity of zinc oxide (found in white pigment) may be toxic locally because of a deregulation of the homeostasis of zinc and other metals which compete with zinc, like copper or iron [13]. After intradermal injection, pigments (under micro- or nanoparticulate form) are internalized by three main cells: fibroblasts, neutrophils, and macrophages. Neutrophils are mainly present at the site of injection immediately after the injection due to mechanical injuries comprising blood losses, superficial infections [14], inflammations, etc. caused by the insertion of the needle into the dermis. These short-lived cells (about $24 \mathrm{~h}$ ) are then quickly eliminated by macrophages via the efferocytosis process and are consequently absent from the tattoo site in the long term. Fibroblasts internalize a low quantity of pigments contrary to macrophages which are professional phagocytic cells and ensure the lifelong persistence of tattoo inks in the dermis due to successive cycles of pigment capture, release and recapture. Indeed, dead macrophages are replaced by mostly new monocyte-derived macrophages, or, to a lesser extent, via a local process of self-renewal $[15,16]$.

In this article, we decided to assess the immediate and persistent effects of some pigments used in tattoo inks on macrophages because of their key role in the persistence of tattoos $[15,16]$. An impairment of their functionalities could induce damage to tissues and cause other diseases $[17,18]$. Furthermore, several articles showed that tattoo ink pigments can be found in lymph nodes due to both passive transport and active transport via macrophages [19]. This is especially true several weeks after the injection of tattoo ink when around $30 \%$ of the ink has been eliminated via blood or lymphatic circulation [20-22]. However, the presence of pigmentloaded macrophages in lymph nodes can be due to the migration of particle-loaded macrophages from the tattoo site to the draining lymph nodes, as suggested by some authors in the case of other mineral particles $[23,24]$. Whatever the mechanism, a massive absorption of 
pigments by macrophages might change their functions and thus, alter immune homeostasis at the tattoo site and at distal sites such as lymph nodes.

The present article investigates cobalt and zinc pigments which constitute a wide range of colors found in tattoos (from purple to green and white) $[25,26]$. Although the exact nature of the pigments used in tattoo inks is not disclosed, as it is considered to be a trade secret, we chose to test three cobalt-based pigments referenced in the Colour Index International as PG19 (dark green), PB28 (blue), and PV14 (purple), and one zinc-based pigment referenced as PW4 (white). Cobalt-based tattoo inks are authorized because the pigments themselves are authorized. However, cobalt is both an essential element (given that it is a cofactor of vitamin B12) and a toxic one at high doses [27]. It has shown deleterious effects on fibroblasts [28], leukocytes [29] and macrophages [30,31] , and also a long-term carcinogenic potential linked to a slow release [32]. Thus, a progressive release of cobalt from pigments internalized by the macrophages may lead to an alteration of their functions and phenotypes. Zinc is an essential trace element in low quantity and the recommended dietary allowance is between 8 and 11 $\mathrm{mg}$ /day for adults. Moreover, zinc plays an important role in numerous biological functions (zinc is a co-factor in enzymatic reactions, vitamin A metabolism, and immunoregulation) [33]. However, an excessive absorption of zinc is considered to be toxic [34]. Zinc oxide nanoparticles are already known to have a toxic effect on immune cells such as macrophages [35]. Toxicity can be explained by the dissolution of these nanoparticles in acidic compartments (lysosomes) which release zinc ions $[36,37]$. This mechanism may be the cause of the potential long-term adverse effects of cobalt and zinc-based pigments, a fact which justifies the relevance of the present work. To this end, we used an in vitro murine macrophage system in load and recovery mode in which the cells are first loaded with particles over 24 hours and then cultured without adding particles for three days [38,39].

\section{Materials and methods}

\subsection{Pigment characterization}

\subsubsection{Pigment description}

Pigment Blue 28 (cobalt aluminate, $\mathrm{CoAl}_{2} \mathrm{O}_{4}$ ), Pigment Violet 14 (cobalt phosphate) and Pigment White 4 (zinc oxide) were purchased from Kama Pigments (Montreal, Canada). Pigment green 19 (mixed cobalt zinc oxide, deep cobalt green CO804) was purchased from Tokyo Pigment (Tokyo, Japan). Corundum (aluminum oxide spinel) was purchased from Sigma ((SaintQuentin-Fallavier, France).

Pigments were received as powders. They were suspended in gum arabic $(100 \mathrm{mg} / \mathrm{ml})$ that had been previously sterilized overnight at $80^{\circ} \mathrm{C}$, with gum arabic thus being used as an anti-agglomeration reagent. Then, the suspension of pigments $(100 \mathrm{mg} / \mathrm{mL})$ was sterilized overnight again before being was sonicated in a Vibra Cell VC 750 sonicator equipped with a Cup Horn probe (VWR, Fontenay-sous-Bois, France) with the following settings: time $=30 \mathrm{~min}-1 \mathrm{sec}-$ ond $\mathrm{ON}, 1$ second $\mathrm{OFF}-$ Amplitude $=60 \%$, corresponding to $90 \mathrm{~W} / \mathrm{pulse}$.

\subsubsection{Dynamic Light Scattering (DLS)}

The pigments were diluted to $100 \mu \mathrm{g} / \mathrm{ml}$ with water or culture medium and they transferred in UVette $^{\circledR}$ 220-1600 nm (catalog number: 0030106.300, Eppendorf, Montesson, France). Then, 
the size and dispersity of pigments were measured via Dynamics Light Scattering (DLS) using Wyatt Dynapro Nanostar (Wyatt Technology, Santa Barbara, CA, USA).

\subsubsection{Transmission Electronic Microscopy (TEM)}

Negative Stain On Grid Technique (SOG): $10 \mu \mathrm{L}$ were added to a glow discharge grid coated with a carbon supporting film for 3 minutes. The excess solution was soaked off using a filter paper and the grid was air-dried. The images were taken under low dose conditions $(<10$ e- $/ \AA 2)$ with defocus values comprised between 1.2 and $2.5 \mu \mathrm{m}$ on a Tecnai $12 \mathrm{LaB} 6$ electron microscope at $120 \mathrm{kV}$ accelerating voltage using CCD Camera Gatan Orius 1000. The measurement was processed with Image $\mathrm{J}$.

\subsection{Cell culture and viability assay}

The mouse macrophage cell line J774A1 was purchased from the European Cell Culture Collection (Salisbury, UK). For cell maintenance, cells were cultured in DMEM containing 10\% of fetal bovine serum (FBS) and $5 \mu \mathrm{g} / \mathrm{ml}$ of Ciprofloxacin. Cells were seeded every 2 days at 250,000 cells $/ \mathrm{ml}$ and harvested at 1 million cells $/ \mathrm{ml}$.

For treatment with pigments, the following schemes of exposure were used:

i) An acute (24 hours) exposure with pigments: cells were seeded in 12-well adherent or nonadherent plates (according to the test) at 1 million cells/ml in DMEM containing horse serum $1 \%$ (HS $1 \%$ ) and $5 \mu \mathrm{g} / \mathrm{ml}$ of Ciprofloxacin. Cells were exposed to pigments on the following day and analyzed at the end of the $24 \mathrm{~h}$-period of exposure to pigments.

ii) A recovery exposure for 4 days: Cells were seeded in 12-well adherent plates at 1 million cells $/ \mathrm{ml}$ in DMEM supplemented with horse serum, as described above. After 24 hours of exposure to pigments, the medium was changed in order to remove pigments. The fresh medium was left for another 48 hours and changed again for 24 hours before cell harvest The choice of a medium supplemented with a low serum concentration was made in order to limit cell proliferation during the recovery period [40]. Indeed, cell proliferation during recovery has been observed before [38] and is not likely to reflect the in vivo situation.

After exposing the cells to various concentrations of pigments, the viability of the cells was tested. Cells were flushed and harvested with PBS and centrifuged at $200 \mathrm{~g}$ for $5 \mathrm{~min}$. Pellets were resuspended in PBS with propidium iodide (PI) at a final concentration of $1 \mu \mathrm{g} / \mathrm{ml}$. The percentage of viability was measured via a FacsCalibur flow cytometer equipped with the CellQuest software program 6.0 (Becton Dickinson Biosciences, Le Pont-de-Claix, France) and settings corresponding to PI (480 nm excitation and $600 \mathrm{~nm}$ emission). For every pigment tested, the LD20 was determined.

\subsection{ICP-AES: Pigment Dissolution}

\subsubsection{In vitro dissolution}

Pigments at just below the LD20 concentration: $2.5 \mu \mathrm{g} / \mathrm{ml}$ and $500 \mu \mathrm{g} / \mathrm{ml}$ were mineralized in aqua regia (Mixture of nitric acid and hydrochloric acid, optimally in a molar ratio of 1:3). Samples were diluted in $10 \%$ nitric acid prior to analysis by inductively coupled plasma atomic emission spectroscopy (ICP-AES) on a Shimadzu ICP 9000 with Mini plasma Torch instrument used in axial reading mode. A standard range of cobalt, zinc and aluminum (from $3.9 \mu \mathrm{g} / \mathrm{L}$ to $10 \mathrm{mg} / \mathrm{L}$ ) was prepared for quantification. 


\subsubsection{In vivo dissolution}

Cells were seeded in 6-well plates at 1 million cells $/ \mathrm{ml}$ in DMEM containing $1 \%$ horse serum and $5 \mu \mathrm{g} / \mathrm{ml}$ Ciprofloxacin. They were exposed to nanoparticles on the following day. For recovery exposure, the medium was changed to remove the pigments and left for another 48 hours. The medium was changed one more time and the cells were left for 24 hours in culture medium. After $24 \mathrm{~h}$ (acute exposure) and $96 \mathrm{~h}$ (recovery exposure). Following medium removal, the cells were rinsed with PBS $1 \mathrm{X}$ and then lysed with $600 \mu 1$ lysis buffer (HEPES 5 $\mathrm{mM}$, spermine tetrahydrochloride $0.75 \mathrm{mM}$, SB 3-14 0.1\%). $50 \mu 1$ of the crude lysate were collected and total amount of protein was quantified with a modified dye-binding assay [41]. The remaining lysate was centrifuged at $10,000 \mathrm{~g}$ for 10 minutes to sediment the nuclei and the undissolved pigments. Finally, the supernatant was collected. Samples were kept at $-20^{\circ} \mathrm{C}$ until mineralization.

The samples were thawed and mineralized by the addition of one volume of Suprapure $65 \%$ $\mathrm{HNO}_{3}$ and incubated on a rotating wheel at room temperature for $18 \mathrm{~h}$. The samples were then diluted up to $6 \mathrm{ml}$ with $10 \%$ nitric acid and the metal concentrations were measured as described above. The results were normalized by measuring the protein concentration (used as an indicator for cell number) in the samples.

\subsection{Internalization ability}

\subsubsection{Phagocytic activity measurement}

The phagocytic activity was measured as previously described $[42,43]$ using fluorescent latex beads (solid $=2.5 \%, 1 \mu \mathrm{m}$ diameter fluorescent yellow-green, catalog number $\mathrm{L} 4655$ from Sigma). The green fluorescence internalized by the cells allows to quantify the phagocytic activity. Cell culture was performed as described above. Cells were seeded in 12-well plates and exposed to pigments (acute or recovery exposure) at $37^{\circ} \mathrm{C}, 5 \% \mathrm{CO}_{2}$. The fluorescent beads were coated in a mixture of horse serum $50 \%$ and PBS $1 \mathrm{X} 50 \%$ for $30 \mathrm{~min}$ at $37^{\circ} \mathrm{C}(2.2 \mu \mathrm{L}$ of fluorescent latex beads for $1 \mathrm{ml}) .100 \mu \mathrm{L} / \mathrm{ml}$ of this solution were added to cell culture, and then, cells were incubated for 3 hours at $37^{\circ} \mathrm{C}$. Cells were harvested, washed with PBS $1 \mathrm{X}$, and centrifuged for $5 \mathrm{~min}$ at $1200 \mathrm{rpm}$. The pellets were suspended with $400 \mu 1$ in PBS1X - propidium iodide $1 \mu \mathrm{g} / \mathrm{ml}$ and analyzed by flow cytometry.

\subsubsection{Neutral red assay}

This stain dyes lysosomes via active transport, and is thus a good indirect assay for lysosomal function. Cells were seeded in adherent 12-well plates and exposed to pigments (acute or recovery exposure) at $37^{\circ} \mathrm{C}, 5 \% \mathrm{CO}_{2} .2 \mathrm{mg} / \mathrm{ml}$ neutral red in EtOH $50 \%$ were prepared and $10 \mu \mathrm{l}$ of this solution were added to every well containing $1 \mathrm{ml}$ of culture medium and incubated for 2 hours at $37^{\circ} \mathrm{C}$. After incubation, cells were washed twice with PBS and eluted with $2 \mathrm{ml}$ of acid-alcohol solution (acetic acid 1\% v/v, ethanol 50\% v/v). The plates were incubated for $30 \mathrm{~min}$ at room temperature on a rotating table. The red color released was read at $540 \mathrm{~nm}$ [44]. To normalize the results, the number of adherent cells was estimated via a crystal violet assay. The fixed cell layer was rinsed twice with PBS and stained with crystal violet ( $4 \mu \mathrm{g} / \mathrm{ml}$ in PBS) for 30 minutes. Then, the cell layer was rinsed twice with PBS before elution with $1 \mathrm{ml}$ of acidalcohol solution. The purple color released was read at $590 \mathrm{~nm}$ using a spectrophotometer. The $540 \mathrm{~nm} / 590 \mathrm{~nm}$ absorbance ratio was used as an index for the lysosomal functionality of the cells. 


\subsection{Inflammatory capacity assay}

\subsubsection{Nitric oxide (NO) production}

The cells were grown to confluence in 12-well plates (harvested at 1 million cells $/ \mathrm{ml}$ ). Half of the wells were treated with $200 \mathrm{ng} / \mathrm{ml}$ LPS, and arginine monohydrochloride was added to all the wells ( $5 \mathrm{nM}$ final concentration) to give a high concentration of substrate for NO synthase. After 18 hours of incubation, the cell culture medium was recovered, centrifuged at $15,000 \mathrm{~g}$ for $15 \mathrm{~min}$ to remove pigments, non-adherent cells and debris. $500 \mu \mathrm{L}$ of supernatant were collected. After the addition of an equal volume of Griess reagent, the mixture was incubated at room temperature for $20 \mathrm{~min}$ in order to wait for the completion of the reaction. The absorbance was read at $540 \mathrm{~nm}$. To normalize the results, the number of cells in the culture plate was estimated via a crystal violet assay. The cell layer was rinsed twice with PBS and fixed with an acid-alcohol solution (acetic acid $1 \% \mathrm{v} / \mathrm{v}$, ethanol $50 \% \mathrm{v} / \mathrm{v}$ ) for 30 minutes. The cell layers were then stained with crystal violet as described in section 2.4.2.

\subsubsection{Cytokine measurement}

Tumor necrosis factor (TNF $\alpha$ ) and interleukin 6 (IL-6) were measured in the supernatant from cultured cells exposed to pigments and/or activated by LPS $200 \mathrm{ng} / \mathrm{ml}$, using the Mouse Inflammation Cytometric Bead Array kit (reference: BD Biosciences, Rungis, France) according to the manufacturer's instructions. Measurements were performed on a Facscalibur flow cytometer, and the concentrations of cytokines secreted were assessed using FCAP Array Software.

\subsection{Comet assay}

The presence of strand breaks in the DNA of the cells exposed to the particles was evaluated using the alkaline version of the comet assay, as described above [45]. After exposure to particles, cells were collected using trypsin and stored at $-80^{\circ} \mathrm{C}$ in freezing buffer $(85.5 \mathrm{~g} / \mathrm{L}$ sucrose, $50 \mathrm{ml} / \mathrm{L}$ DMSO prepared in citrate buffer (11.8 g/L), $\mathrm{pH} 7.6)$. Ten thousand cells were mixed with $0.6 \%$ low melting point agarose (LMPA) and two drops of this mixture were put on a slide that had previously been coated with agarose. The cell/LMPA mixture was left to solidify on ice for $10 \mathrm{~min}$, and then slides were immersed in cold lysis buffer $(2.5 \mathrm{M} \mathrm{NaCl}, 100 \mathrm{mM}$ EDTA, $10 \mathrm{mM}$ Tris, $10 \%$ DMSO, $1 \%$ Triton $\mathrm{X}-100, \mathrm{pH} 10)$ and incubated overnight at $4^{\circ} \mathrm{C}$. Slides were then rinsed with PBS, and DNA was left to unwind for 30min in the electrophoresis buffer (300 $\mathrm{mM} \mathrm{NaOH}, 1 \mathrm{mM}$ EDTA, $\mathrm{pH}>13$ ). Electrophoresis was performed in a vertical electrophoresis tank (Cleaver Scientific) at $0.7 \mathrm{~V} / \mathrm{cm}$ for $30 \mathrm{~min}$. Slides were then neutralized in PBS and stained with $50 \mu \mathrm{L}$ of GelRed (Thermofisher Scientific). The analysis consisted in recording the $\%$ tail DNA on 50 cells per gel using the Comet IV software (Perceptive Instruments, Suffolk, UK). Experiments were performed three times independently, with two technical replicates per condition in each independent experiment. The cells exposed for $24 \mathrm{~h}$ to $100 \mu \mathrm{M}$ of methyl methanesulfonate were used as positive control, and one control slide exposed to $\mathrm{H}_{2} \mathrm{O}_{2}$ was used as positive control for the electrophoretic migration.

\subsection{Antibody assays}

Cells previously exposed to pigments for $24 \mathrm{~h}$ are then labeled with anti-CD11b antibody (BD Pharmigen, catalogue number 553310, Becton Dickinson Biosciences, Le Pont-de-Claix, 
France) as follows: in a 96-well round-bottom plate, $200 \mu \mathrm{L}$ of cell suspension containing 1 million cells/well is added to each well. The plate is then centrifuged for 5 minutes at $800 \mathrm{~g}$. After turning the plate upside down, $50 \mu \mathrm{L}$ of Fc block diluted at $10 \mu \mathrm{g} / \mathrm{mL}$ in PBS $+2 \% \mathrm{SVF}$ were added to each well. The plate was then left to incubate for 10 minutes at room temperature. Then $150 \mu \mathrm{L}$ of $\mathrm{PBS}+2 \% \mathrm{SVF}$ were added and centrifuged at $800 \mathrm{~g}$. After turning the plate upside down, $50 \mu \mathrm{L}$ of $\mathrm{CD} 11 \mathrm{~b}$ antibody at $20 \mu \mathrm{g} / \mathrm{mL}$ were added. The plate was then incubated for 20 minutes in the dark and at room temperature. After incubation, the cells were rinsed by adding $150 \mu \mathrm{L}$ of PBS $+2 \% \mathrm{SVF}$ to each well. The plate was centrifuged for 5 minutes at $800 \mathrm{~g}$ and then emptied by turning the plate upside down. Finally, the cells were resuspended in PBS $+2 \% \mathrm{SVF}+$ propidium iodide $(1 \mu \mathrm{g} / \mathrm{mL}$ final concentration $)$ and transferred to FACS tubes (final volume $=300 \mu \mathrm{L}$ ).

\subsection{Numerical analysis}

A Student's $t$-test was applied to all the results. Data are presented as mean $+/$ - standard deviations; $* \mathrm{p}<0.05, * * \mathrm{p}<0.01, * * * \mathrm{p}<0.001$. The systematic use of viability markers (propidium iodide or Sytox red) allows for analysis of live cells only. Biological experiments were performed on four independent biological replicates.

\section{Results}

After characterizing the three cobalt-based pigments and determining their respective LD20, we chose to compare the effects of pigments on J774 macrophages and present the results corresponding to the two schemes of exposure tested. The acute effects of cobalt-based pigments were compared to recovery exposure in order to visualize specific persistent effects. For the two schemes of exposures, a corundum control was used in order to distinguish the effects due to the internalization of particles from the specificities of the pigmentary materials tested.

\subsection{Physical characterization of pigments}

The size (hydrodynamic diameter) and the size distribution (polydispersity percentage) of the pigments in suspension were characterized using DLS. Size distribution is deemed monodisperse when the polydispersity percentage is inferior to $15 \%$. The results in Figure 1A and supplementary Data 1 show a high diversity of sizes for all the pigments tested. Consequently, dispersity cannot be measured. However, the average hydrodynamic diameter of each pigment tested was very different. Indeed, the average hydrodynamic size of PV14 was approximately $994 \mathrm{~nm}$ in H2O medium and $860 \mathrm{~nm}$ in DMEM culture medium. For PG19, the size was 196 $\mathrm{nm}$ in $\mathrm{H} 2 \mathrm{O}$ and $98 \mathrm{~nm}$ in DMEM. For PB28, the size was $517 \mathrm{~nm}$ in $\mathrm{H} 2 \mathrm{O}$ and $441 \mathrm{~nm}$ in DMEM. Lastly, for PW4, the size was $242 \mathrm{~nm}$ in $\mathrm{H} 2 \mathrm{O}$ and $177 \mathrm{~nm}$ in DMEM. Size variation between DMEM medium and H2O was not significant. TEM microscopy (Figure 1B) confirmed a high diversity of sizes and shapes for all particle suspensions, both pigments and corundum. TEM microscopy revealed the non-negligible presence of nanoparticles with a size of about $50 \mathrm{~nm}$ in the case of PG19. Microscopic observations also show the presence of nanostructured elements with at least 1 dimension in nanometer size. This can be easily observed in the cases of PB28 and PW4. Supplementary data 1 provides more precise measurements (not only the size average) recorded via DLS and shows the presence of submicrometer objects or nano-objects for all the pigments tested. For example, in the case of PB28, some objects have a hydrodynamic diameter between 70 and $113 \mathrm{~nm}$. In the cases of PV14 and PG19, we observed objects with a hydrodynamic diameter between 2 and $20 \mathrm{~nm}$, and between 8 and $110 \mathrm{~nm}$, respectively. Finally, in the case of PW4, the objects observed have a diameter between 
6 and $124 \mathrm{~nm}$. The results confirm the presence of nano-elements in addition to microparticles in the pigments tested.

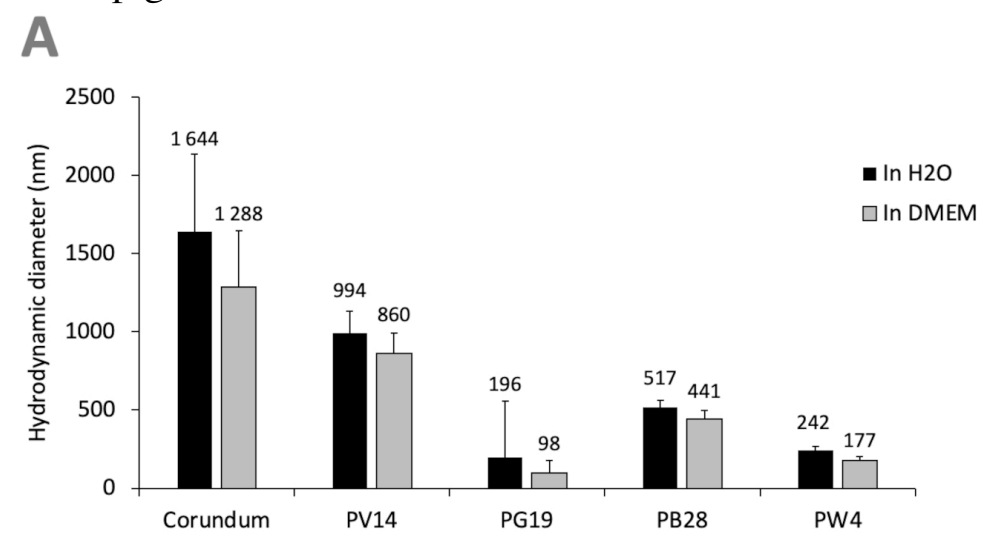

B

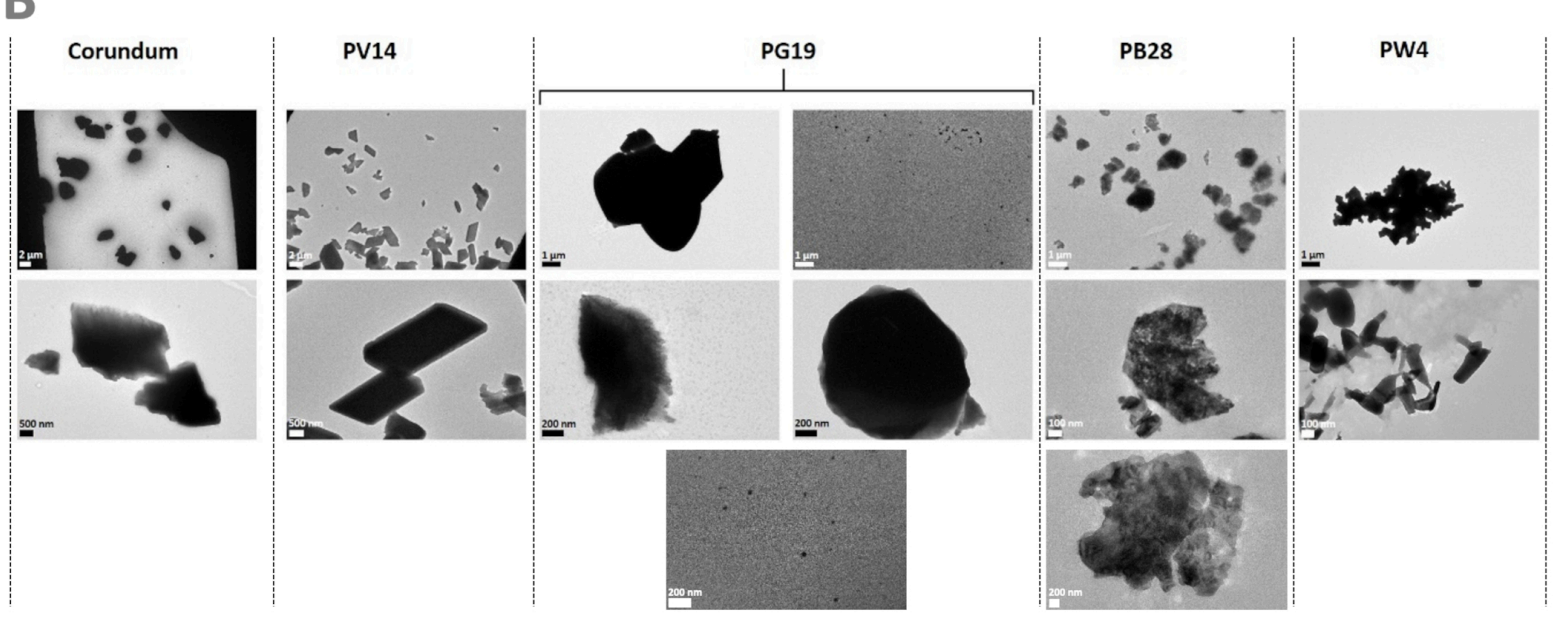

Figure 1 - Characterization of pigments PV14, PG19, PB28, PW4 and their corundum control. Panel A: Hydrodynamic diameter measurement by $\mathrm{DLS}$ in $\mathrm{H}_{2} \mathrm{O}$ (in black) and DMEM culture medium (in grey). Panel B: visualization of pigments by TEM microscopy in $\mathrm{H}_{2} \mathrm{O}$.

\subsection{Chemical characterization of pigments}

For two of the pigments used in this study, namely Pigment Violet 14 and Pigment Blue 28, the formulas are known (cobalt phosphate $\mathrm{Co}_{3}(\mathrm{PO} 4)_{2}$ and $\mathrm{CoAl}_{2} \mathrm{O}_{4}$, respectively). Pigment Green 19 is described as a mixture of cobalt and zinc oxide (Rinmann's green) in undisclosed proportions, so that the chemical composition of the pigment had to be determined. To this end, we analyzed the three cobalt-based-pigments to determine their content of aluminum, zinc, and cobalt. For the purpose of comparison, corundum $\left(\mathrm{Al}_{2} \mathrm{O}_{3}\right.$ spinel) was included in the analysis, as it has a similar spinel structure as Pigment Blue 28. Pigment White 4, which is also composed of zinc oxide, was analyzed in order to be compared with Pigment Green 19.

The results, shown in Table 1, allow to draw several conclusions.

Table 1: metal analysis of the pigments.

$$
\operatorname{Al}(\mu \mathrm{g} / \mathrm{l}) \quad \operatorname{Co}(\mu \mathrm{g} / \mathrm{l}) \quad \text { Zn }(\mu \mathrm{g} / \mathrm{l})
$$




\begin{tabular}{l|lll} 
& $\begin{array}{l}\text { Measured af- } \\
\text { ter minerali- } \\
\text { zation }\end{array}$ & $\begin{array}{l}\text { Measured af- } \\
\text { ter minerali- } \\
\text { zation }\end{array}$ & $\begin{array}{l}\text { Measured af- } \\
\text { ter minerali- } \\
\text { zation }\end{array}$ \\
\hline Negative control & 82.9 & 0 & 156 \\
Arabic gum 500 $\boldsymbol{\mu g} / \mathbf{m l}$ & 158 & 0 & 77.4 \\
Corundum 2.5 $\boldsymbol{\mu \mathbf { g } / \mathbf { m l }}$ & 90 & 0 & 64.5 \\
Corundum 500 $\boldsymbol{\mu g} / \mathbf{m l}$ & 448 & 0 & 129 \\
PV14 2.5 $\boldsymbol{\mu g} / \mathbf{m l}$ & 92.9 & 798 & 76.6 \\
PG19 2.5 $\boldsymbol{\mu \mathbf { g } / \mathbf { m l }}$ & 139 & 48 & 1810 \\
PB28 500 $\boldsymbol{\mu \mathbf { g } / \mathbf { m l }}$ & 2600 & 641 & 85.2 \\
PW4 2.5 $\mathbf{~ g / m l ~}$ & 57.2 & 42.7 & 1420
\end{tabular}

As the input concentrations of the pigments are known, these experimental results allowed to have a clearer understanding of the mineralization efficiency for each pigment (the experiment was performed only once). First, the mineralization/measurement efficiency of PV14 was around $60 \%$. Second, the mineralization/measurement efficiency of both spinels (corundum and PB28) was very low, below $1 \%$.

Third, the mineralization/measurement efficiency of PW4 was 70\%. Finally, the mineralization/measurement efficiency of PG19 was close to quantitative (92\% yield) and allowed to determine the relative proportion of zinc and cobalt in the pigment. Thus, the pigment used in this study could be described as $\mathrm{Co}_{0.028} \mathrm{Zn}_{0.912} \mathrm{O}$.

\subsection{Determination of pigment dose for cellular assays}

To carry out the following functional tests, it was necessary to determine the concentration of pigments allowing to obtain the best compromise between a good viability and observation of biological effects. We thus decided to limit the concentration at or just below the lethal dose 20 (LD 20), in order to avoid excess mortality in case this dose varies. Given the particulate nature of the pigments, such variations are likely to occur. Because nanoparticles are known to interfere with many methods of viability estimation [46], we chose a dye exclusion test. According to the data displayed in Figure 2, we considered that the optimal dose was $2.5 \mu \mathrm{g} / \mathrm{ml}$ for PV14, PG19 and PW4, and $500 \mu \mathrm{g} / \mathrm{ml}$ for PB28.

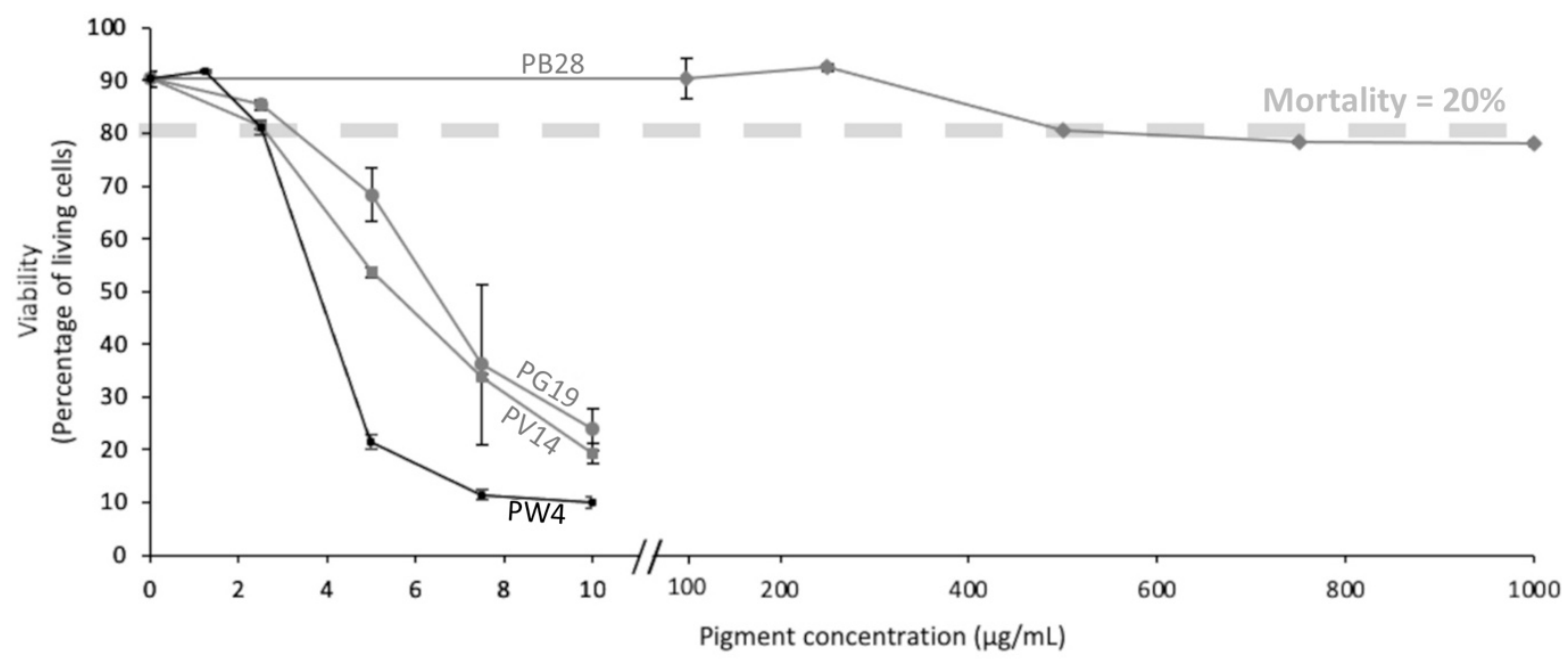

Figure 2 - Viability of J774 cells. Cells were exposed to variable doses of pigments (PV14, PG19, PW4 and PB28) for 24h. Viability was measured using propidium iodide (1 $\mathrm{g} / \mathrm{ml})$. 


\subsection{Internalization ability}

\subsubsection{Measurement of phagocytic activity}

To determine whether the pigments induce changes to the main functions of macrophages, a phagocytosis assay was carried out for acute and recovery exposure. The results in Figures $3 \mathrm{~A}$ and $3 \mathrm{C}$ showed that under acute exposure, PV14 $(2.5 \mu \mathrm{g} / \mathrm{ml}), \mathrm{PG} 19(2.5 \mu \mathrm{g} / \mathrm{mL})$ and PW4 $(2.5$ $\mu \mathrm{g} / \mathrm{mL}$ ) induced a decrease in the proportion of phagocytic cells in comparison to control without treatment and corundum $(2.5 \mu \mathrm{g} / \mathrm{ml})$ control. For PV14 $(2.5 \mu \mathrm{g} / \mathrm{mL})$, the percentage of phagocytic cells decreased by about $10 \%$ in comparison to the two controls. For PG19 (2.5 $\mu \mathrm{g} / \mathrm{ml}$ ), we observed a decline of 14 and $13 \%$ in comparison to control without treatment and corundum $(2.5 \mu \mathrm{g} / \mathrm{ml})$, respectively. For PW4, there was a decrease of 12 and $11 \%$ in comparison to control without treatment and corundum $(2.5 \mu \mathrm{g} / \mathrm{ml})$, respectively. Under recovery exposure, the proportion of phagocytic cells remained significantly lower than controls for PG19 $(2.5 \mu \mathrm{g} / \mathrm{mL})$ and PW4 $(2.5 \mu \mathrm{g} / \mathrm{mL})$ only. Indeed, for PG19, the percentage of phagocytic cells decreased by $18 \%$ and $14 \%$ in comparison to control without treatment and corundum $(2.5$ $\mu \mathrm{g} / \mathrm{mL})$. The decline observed for PW4 was similar (between 19 and $15 \%)$. PV14 $(2.5 \mu \mathrm{g} / \mathrm{mL}$ ) did not induce significant changes in comparison to control without treatment. Thus, at 2.5 $\mu \mathrm{g} / \mathrm{mL}$, short-term and persistent effects on the phagocytic activity were only observed for PG19 $(2.5 \mu \mathrm{g} / \mathrm{mL})$ and PW4 $(2.5 \mu \mathrm{g} / \mathrm{mL})$. These two pigments contain zinc (in addition to cobalt, for PG19). PV14 $(2.5 \mu \mathrm{g} / \mathrm{mL})$ is the only pigment that induced solely an acute effect. Under acute exposure, the results presented in Figures 3B and 3D showed that PB28 (500 $\mu \mathrm{g} / \mathrm{mL})$ and the corundum control $(500 \mu \mathrm{g} / \mathrm{ml})$ induced a significant decrease in phagocytic cells (-22\% and $-28 \%$, respectively) in comparison to control without treatment. No significant differences between the corundum $(500 \mu \mathrm{g} / \mathrm{ml})$ and PB28 $(500 \mu \mathrm{g} / \mathrm{ml})$ conditions were observed. Therefore, the reduction of the phagocytic activity was due to a high concentration of particles, regardless of the nature of the particulate material. However, these decreases were maintained (and, perhaps, aggravated) only for PB28 $(500 \mu \mathrm{g} / \mathrm{ml})$ under recovery exposure. Indeed, the percentage of phagocytic cells declined by $30 \%$.

Under acute exposure, we observed a significant decrease in the Mean Fluorescence Intensity (MFI) for PV14 $(2.5 \mu \mathrm{g} / \mathrm{mL})(\mathrm{MFI}=211)$ and PG19 $(2.5 \mu \mathrm{g} / \mathrm{mL})(\mathrm{MFI}=205)$ in comparison to their controls $(\mathrm{MFI}=242$ for control without treatment and MFI $=229$ for corundum (2.5 $\mu \mathrm{g} / \mathrm{mL}))$. Under recovery exposure, the decrease continued for PG19 $(2.5 \mu \mathrm{g} / \mathrm{mL})(\mathrm{MFI}=177)$ only. Surprisingly, for PV14, the MFI significantly increased to 278.

For PB28, we observed a similar decrease in the MFI compared to corundum $(500 \mu \mathrm{g} / \mathrm{mL})$ under acute exposure (MFI = 279 and 271, respectively, instead of 321 for control without treatment). Under recovery exposure, the decline of the MFI for PB28 continued in comparison to controls. 

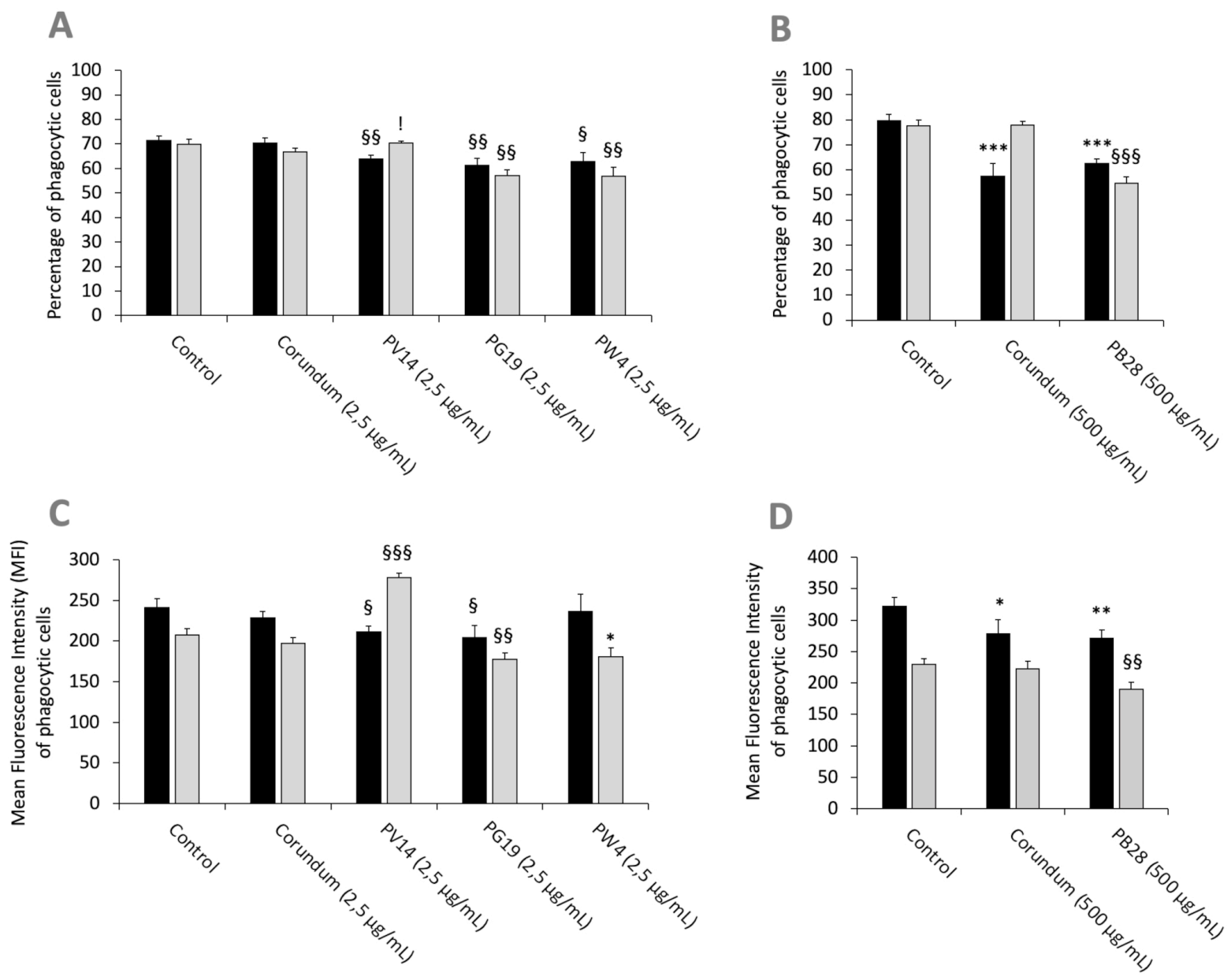

Figure 3 - Phagocytic capacity.

Black bars: acute exposure (24 hours). Grey bars: Exposure for 24 hours followed by a 3day post-exposure recovery period. Panel A: conditions with $2.5 \mu \mathrm{g} / \mathrm{ml}$ of particle suspension. Percentage of cells able to phagocytose fluorescent FITC-labeled latex beads (positive cells). Panel B: conditions with $500 \mathrm{\mu g} / \mathrm{ml}$ of particle suspension. Percentage of cells able to phagocytose fluorescent FITC-labeled latex beads (positive cells). Panel C: measurement of the phagocytic ability (mean fluorescent intensity) of positive cells. Conditions with $2.5 \mu \mathrm{g} / \mathrm{ml}$ of particle suspension. Panel D: measurement of the phagocytic ability (mean fluorescent intensity) of positive cells. Conditions with $500 \mu \mathrm{g} / \mathrm{ml}$ of particle suspension. Significance of symbols: *: different from negative control only; $\xi$ : different from both negative and corundum controls; !: different from corundum control only. Number of symbols: $1: p<0.05 ; 2: p<0.01 ; 3: p<0.001$.

\subsubsection{Measurement of lysosomal activity}

Besides the phagocytic activity, we tested whether the pigments altered the lysosomal activity. The neutral red uptake assay allows a crude evaluation of the endosomal and lysosomal activities as it requires an active proton pump and undamaged lysosomes. The results in Figures 4A and $4 \mathrm{~B}$ showed no significant differences regarding the uptake of neutral red between the conditions with and without pigment, under both acute and recovery exposure. Thus, no damage to the endosome-lysosome pathway was observed, thereby confirming that the decrease in phagocytic ability in the presence of PB28 $(500 \mu \mathrm{g} / \mathrm{ml})$ and corundum $(500 \mu \mathrm{g} / \mathrm{ml})$ impacted solely the phagocytosis process without modifying lysosomal integrity. 

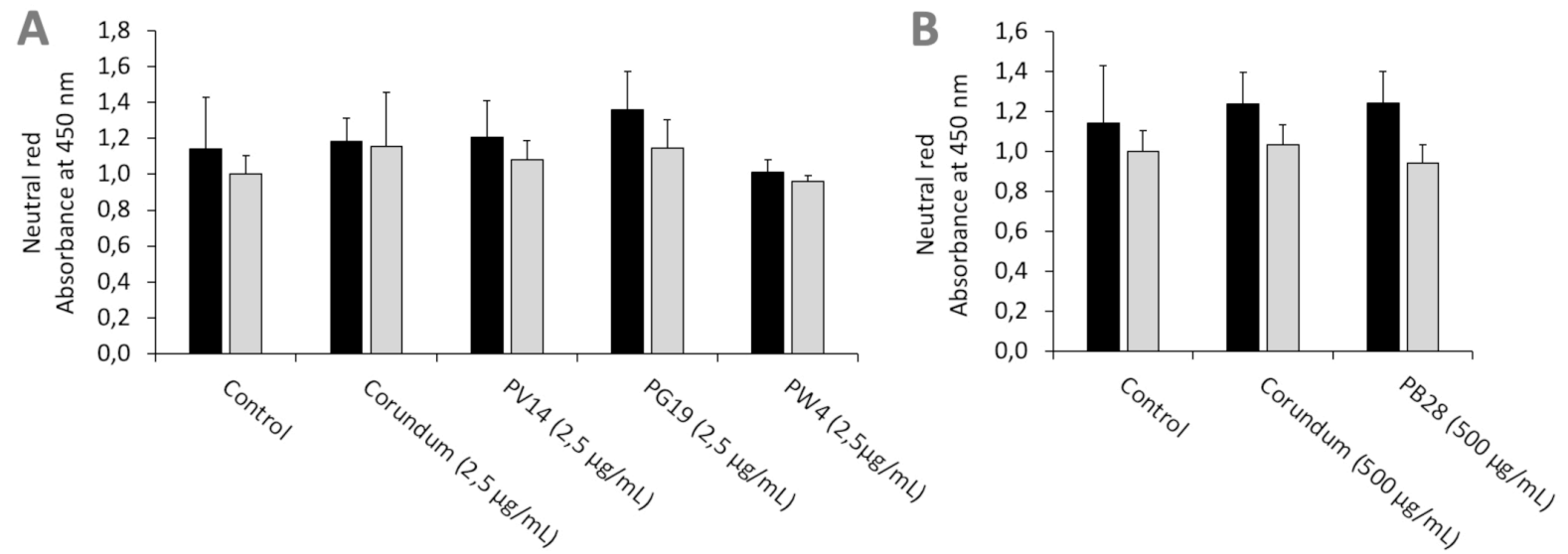

Figure 4-Neutral red uptake.

Black bars: acute exposure (24 hours). Grey bars: exposure for 24 hours followed by a 3-day post-exposure recovery period. Panel A: conditions with $2.5 \mu \mathrm{g} / \mathrm{ml}$ of particle suspension. Panel B: conditions with $500 \mu \mathrm{g} / \mathrm{ml}$ of particle suspension. After elution, the absorbance of the red color released was read at $540 \mathrm{~nm}$.

\subsection{Intracellular degradation of the pigments}

As the pigments are internalized in large vesicles similar to phagolysosomes, they are exposed to an environment that is both acidic and oxidizing and could cause metal ions to be released from the pigments into the cells. To evaluate this phenomenon, we measured the soluble ion content of cellular extracts after exposure to the pigments, either at the end of the $24 \mathrm{~h}$ exposure phase or at the end of the $72 \mathrm{~h}$ post-exposure period. The results, displayed in Table 2 , show distinct differences between the end of the exposure period on the one hand, and the end of the exposure period on the other.

Table 2: intracellular ion content after exposure to pigments.

\begin{tabular}{|c|c|c|c|c|c|c|c|}
\hline & & & Acute & & & Recovery & \\
\hline & & $\begin{array}{l}\text { ng Al/mg } \\
\text { cell proteins }\end{array}$ & $\begin{array}{l}\mathrm{ng} \mathrm{Co} / \mathrm{mg} \\
\text { cell proteins }\end{array}$ & $\begin{array}{l}\mathrm{ng} \mathrm{Zn} / \mathrm{mg} \\
\text { cell proteins }\end{array}$ & $\begin{array}{l}\mathrm{ng} \mathrm{Al} / \mathrm{mg} \\
\text { cell proteins }\end{array}$ & $\begin{array}{l}\mathrm{ng} \mathrm{Co} / \mathrm{mg} \\
\text { cell proteins }\end{array}$ & $\begin{array}{l}\mathrm{ng} \mathrm{Zn} / \mathrm{mg} \\
\text { cell proteins }\end{array}$ \\
\hline Neg ctrl & & $166 \pm 117$ & $18.6 \pm 20.9$ & $11.1 \pm 17.1$ & $16.9 \pm 41.4$ & $15.2 \pm 14.2$ & $59.5 \pm 19.3$ \\
\hline Arabic gum & $500 \mu \mathrm{g} / \mathrm{ml}$ & $29.5 \pm 35.5$ & $40.8 \pm 46.7$ & $43.2 \pm 38$ & $29.8 \pm 30.2$ & $13.2 \pm 14.9$ & $12.5 \pm 21.5$ \\
\hline Corundum & $2.5 \mu \mathrm{g} / \mathrm{ml}$ & $117.3 \pm 48.2$ & $55.7 \pm 56.5$ & $22.9 \pm 12.2$ & $0.38 \pm 0.94$ & $56.2 \pm 32.2$ & $29.9 \pm 26.5$ \\
\hline Corundum & $500 \mu \mathrm{g} / \mathrm{ml}$ & $748.7 \pm 201.7 *$ & $17.7 \pm 15.7$ & $34.1 \pm 30.9$ & $116.3 \pm 103.9$ & $59.7 \pm 72.8$ & $26 \pm 23.9$ \\
\hline PV14 & $2.5 \mu \mathrm{g} / \mathrm{ml}$ & $17.7 \pm 24.7$ & $225.2 \pm 118.5^{*}$ & $17.4 \pm 14.3$ & 0 & $53.7 \pm 41.7$ & $34.8 \pm 26.8$ \\
\hline PG19 & $2.5 \mu \mathrm{g} / \mathrm{ml}$ & $35.7 \pm 34.1$ & $42.9 \pm 36.5$ & $70.7 \pm 16^{*}$ & $30.8 \pm 35$ & $25.6 \pm 14.7$ & $34.8 \pm 14.9$ \\
\hline PW4 & $2.5 \mu \mathrm{g} / \mathrm{ml}$ & $25.4 \pm 34.4$ & $34 \pm 27.4$ & $97.1 \pm 24$ & $60 \pm 69.2$ & $6.3 \pm 7.1$ & $38.6 \pm 12.2$ \\
\hline PB28 & $500 \mu \mathrm{g} / \mathrm{ml}$ & $1083.6 \pm 181.9 *$ & $125.15 \pm 47.2^{*}$ & $56.8 \pm 58.6^{*}$ & $477.3 \pm 295.3^{*}$ & $145.7 \pm 59.8^{*}$ & $34.1 \pm 38.2$ \\
\hline
\end{tabular}

* Significantly different from control in two-tailed Mann-Whitney U test

At the end of the exposure period, a significant ion release was detected for PV 14 and PB 28. However, this release must be put in perspective with the total metal input. For example, the total input of $1 \mathrm{mg}$ PB28 corresponds to $330 \mu \mathrm{g}$ of cobalt, of which only $28 \mathrm{ng}$ are detected as 
intracellular and soluble, i.e. a $0.01 \%$ solubilization. Furthermore, the amounts of aluminum and cobalt released from PB28 should be very similar, which is not the case in our data. This shows that cells do not accumulate all ions passively, but may either solubilize ions differently or excrete some ions more than others. PV14 appears to be more soluble, with $43 \mathrm{ng}$ of cobalt detected as intracellular and soluble, to be compared with the $2.4 \mu \mathrm{g}$ of cobalt input, i.e. a $1.8 \%$ solubilization.

The results are more difficult to interpret at the end of the recovery period, because the number of cells can vary from one condition to another, for example because some cells detach from the plate, as indicated by lower protein contents. However, a sustained release of cobalt can be seen from PV14 and from PB28.

\subsection{Inflammatory response}

The inflammatory response of macrophages was tested with nitric oxide (NO) and cytokine assays. The responses, under all conditions, were assessed in the presence or absence of inflammatory stimuli such as LPS.

\subsubsection{Nitric oxide production}

We first tested the intrinsic effects of pigments without LPS stimulation. In acute exposure mode, the results in Figures 5A and 5B show that the production of NO increased strongly and significantly for PV14 $(2.5 \mu \mathrm{g} / \mathrm{ml})$, i.e. $9.5 \mu \mathrm{M}$ in comparison to $4.4 \mu \mathrm{M}$ for control without treatment and $2.8 \mu \mathrm{M}$ for corundum $(2.5 \mu \mathrm{g} / \mathrm{mL})$ control. For PG19 $(2.5 \mu \mathrm{g} / \mathrm{mL})$ and PW4 $(2.5$ $\mu \mathrm{g} / \mathrm{mL}$ ), a less significant increase was also observed. Indeed, the secretion of NO was $6.4 \mu \mathrm{M}$ for PG19 $(2.5 \mu \mathrm{g} / \mathrm{mL})$ and $5.2 \mu \mathrm{M}$ for PW4 $(2.5 \mathrm{~g} / \mathrm{mL})$. Thus, this pro-inflammatory effect was specific to these pigments since no increase in NO secretion was observed for corundum $(2.5$ $\mu \mathrm{g} / \mathrm{mL})$. Moreover, PB28 $(500 \mu \mathrm{g} / \mathrm{mL})$ did not induce an intrinsic increase in NO secretion despite a high concentration.

Under recovery exposure, the results showed a persisting and significant increase in NO secretion in the presence of pigment in comparison to their controls. Indeed, NO secretion amounted to $12.8 \mu \mathrm{M}$ for PV14 $(2.5 \mu \mathrm{g} / \mathrm{mL}), 16.4 \mu \mathrm{M}$ for PG19 $(2.5 \mu \mathrm{g} / \mathrm{mL})$ and $14.7 \mu \mathrm{M}$ for PW4 $(2.5 \mu \mathrm{g} / \mathrm{mL})$, but only $7.4 \mu \mathrm{M}$ for control without treatment and $5.8 \mu \mathrm{M}$ for corundum $(2.5 \mu \mathrm{g} / \mathrm{mL})$. For corundum $(500 \mu \mathrm{g} / \mathrm{mL})$ and PB28 $(500 \mu \mathrm{g} / \mathrm{mL})$, the results were more difficult to interpret. Indeed, we observed a surprising increase in NO secretion in the presence of corundum $(500 \mu \mathrm{g} / \mathrm{mL})$ but not in the presence of PB28 $(500 \mu \mathrm{g} / \mathrm{mL})$. However, we can conclude that, contrary to others pigments with a smaller concentration, PB28 $(500 \mu \mathrm{g} / \mathrm{mL})$ cannot induce intrinsic effects on NO secretion after recovery exposure.

After stimulating cells with LPS for the last 18 hours of the experiment, in acute or recovery exposure modes, the results obtained with pigments in comparison to the condition without particles showed that the secretion of $\mathrm{NO}$ remained unchanged for cells exposed to corundum $(2.5 \mu \mathrm{g} / \mathrm{mL}$ and $500 \mu \mathrm{g} / \mathrm{mL})$, PB28 $(500 \mu \mathrm{g} / \mathrm{mL})$ and PG19 $(2.5 \mu \mathrm{g} / \mathrm{mL})$ (Figures 5C and 5D). Under acute exposure, we observed a slight trend toward a significant increase in the concentration of NO for PV14 $(2.5 \mu \mathrm{g} / \mathrm{mL})$ and a decrease in NO secretion $(21.5 \mu \mathrm{M})$ for PW4 $(2.5 \mu \mathrm{g} / \mathrm{mL})$ in comparison to the two controls without treatment and corundum $(2.5 \mu \mathrm{g} / \mathrm{mL})$ (39.4 $\mu \mathrm{M}$ and $39.3 \mu \mathrm{M}$, respectively). Under recovery exposure, PG19 $(2.5 \mu \mathrm{g} / \mathrm{mL})$ and PW4 $(2.5 \mu \mathrm{g} / \mathrm{mL})$ did not induce any change to the secretion of NO in comparison to their controls. However, PV14 $(2.5 \mu \mathrm{g} / \mathrm{mL})$ induced a sharp decline $(15 \mu \mathrm{M})$ in comparison to its controls i.e. $38.2 \mu \mathrm{M}$ and $36.7 \mu \mathrm{M}$ for control without treatment and corundum $(2.5 \mu \mathrm{g} / \mathrm{mL})$, respectively. Moreover, we can observe that for PV14 $(2.5 \mu \mathrm{g} / \mathrm{mL}$-recovery), the level of NO was similar 
with or without LPS stimulation (15 $\mu \mathrm{M}$ with LPS stimulation and $12.8 \mu \mathrm{M}$ without LPS stimulation). No significant changes were observed for PB28 $(500 \mu \mathrm{g} / \mathrm{mL})$ under recovery exposure despite a significant increase in NO secretion for corundum $(500 \mu \mathrm{g} / \mathrm{mL})$ in comparison to the control without treatment.

A
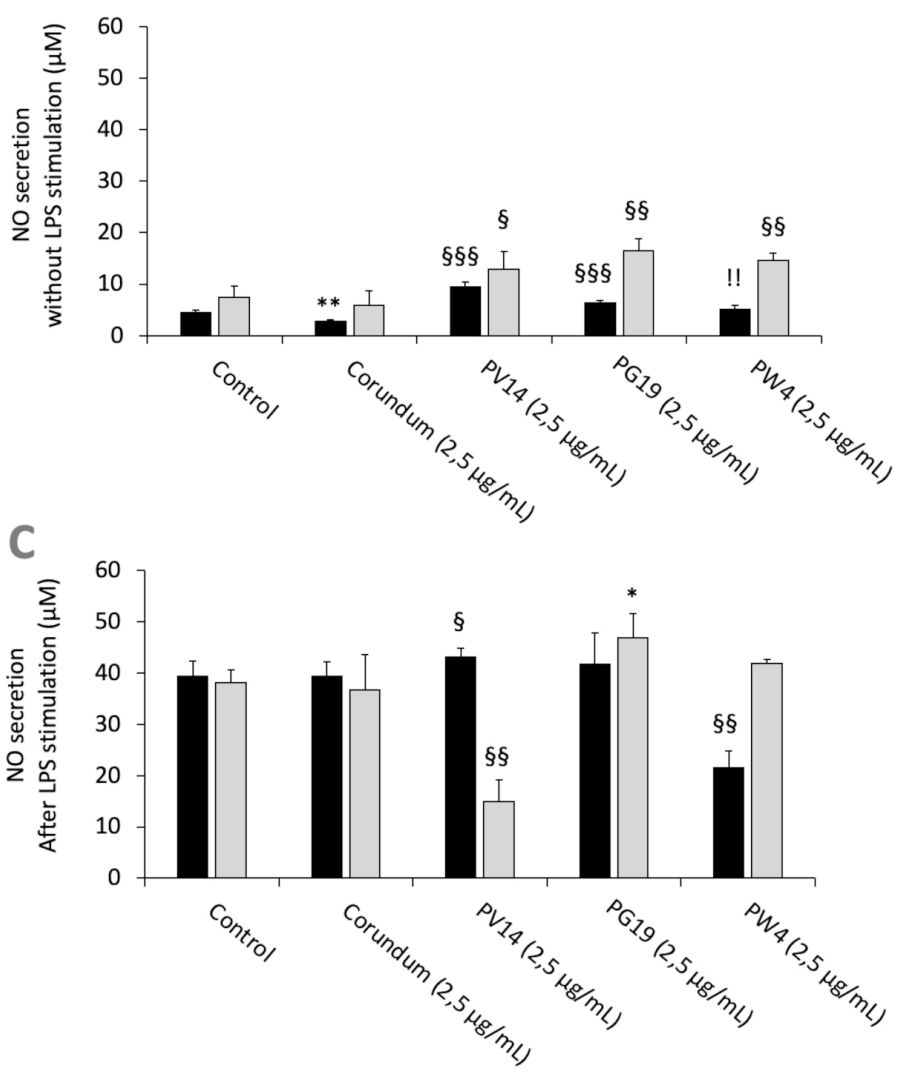

B
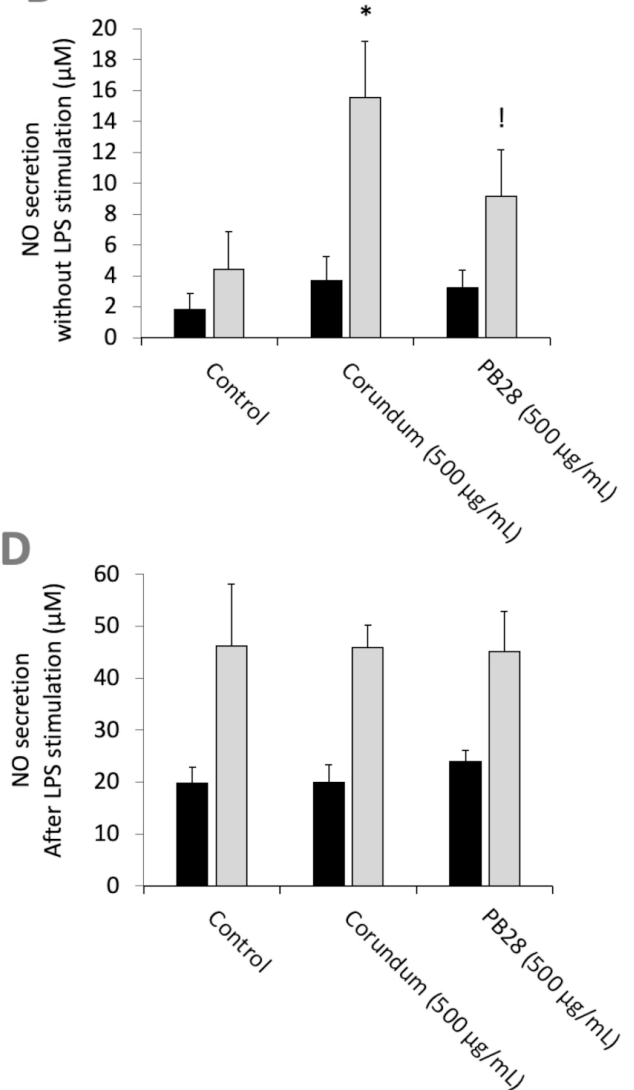

Figure 5 - NO secretion.

Black bars: acute exposure (24 hours). Grey bars: exposure for 24 hours followed by a 3-day post-exposure recovery period. Panel A: NO secretion without LPS stimulation. Conditions with $2.5 \mu \mathrm{g} / \mathrm{ml}$ of particle suspension. Panel B: NO secretion without LPS stimulation. Conditions with $500 \mu \mathrm{g} / \mathrm{ml}$ of particle suspension. Panel C: NO secretion with LPS stimulation. Conditions with $2.5 \mu \mathrm{g} / \mathrm{ml}$ of particle suspension. Panel D: NO secretion with LPS stimulation. Conditions with $500 \mu \mathrm{g} / \mathrm{ml}$ of particle suspension. Significance of symbols: *: different from negative control only; $\S$ : different from both negative and corundum controls; !: different from corundum control only. Number of symbols: $1: p<0.05 ; 2: p<0.01 ; 3: p<0.001$.

\subsubsection{Cytokine secretion}

In order to determine whether pigments induced an intrinsic inflammatory effect, as suggested by the nitric oxide results, the release of cytokines by cells was measured without LPS stimulation. In acute exposure mode, the results in Figures $6 \mathrm{C}$ and $6 \mathrm{D}$ revealed no changes to IL-6 secretion for the conditions PV14 $(2.5 \mu \mathrm{g} / \mathrm{mL})$, PG19 $(2.5 \mu \mathrm{g} / \mathrm{mL})$, and PW4 $(2.5 \mu \mathrm{g} / \mathrm{mL})$ in comparison to their controls. However, IL-6 concentration increased in the presence of corun$\operatorname{dum}(500 \mu \mathrm{g} / \mathrm{mL})$ and PB28 $(500 \mu \mathrm{g} / \mathrm{mL})$ in comparison to control without treatment while no significant differences were observed between PB28 $(500 \mu \mathrm{g} / \mathrm{mL})$ and corundum $(500 \mu \mathrm{g} / \mathrm{mL})$. 
Thus, this increase was due to the presence of a high concentration of particles, independently of the material.

For recovery exposure without LPS stimulation, no significant differences in IL-6 secretion were observed between the different conditions except for PB28 $(500 \mu \mathrm{g} / \mathrm{mL})$. In this case, IL6 secretion increased significantly in comparison to its two controls. Part of the persisting effect observed was certainly due to the high concentration of particles because corundum (500 $\mu \mathrm{g} / \mathrm{mL}$ ) induced also a moderate increase in comparison to control without treatment.

The results in Figures 6A and 6B showed an increase in TNF secretion for PV14 $(2.5 \mu \mathrm{g} / \mathrm{mL})$, PG19 $(2.5 \mu \mathrm{g} / \mathrm{mL})$ and PW4 $(2.5 \mu \mathrm{g} / \mathrm{mL})$ in comparison to control without treatment and corundum $(2.5 \mu \mathrm{g} / \mathrm{mL})$. Both corundum $(500 \mu \mathrm{g} / \mathrm{mL})$ and PB28 $(500 \mu \mathrm{g} / \mathrm{mL})$ induced an increase in TNF in comparison to control without treatment. The results suggest that a high concentration of particles has an effect on TNF secretion independently of the material. Under recovery exposure, no significant differences were observed between the conditions tested except for PB28. Indeed, a slightly significant decrease in TNF concentration was observed: $752 \mathrm{pg} / \mathrm{mL}$ instead of $981 \mathrm{pg} / \mathrm{mL}$ and $1,111 \mathrm{pg} / \mathrm{mL}$ for control without treatment and corundum control (2.5 $\mathrm{pg} / \mathrm{mL})$, respectively.

A
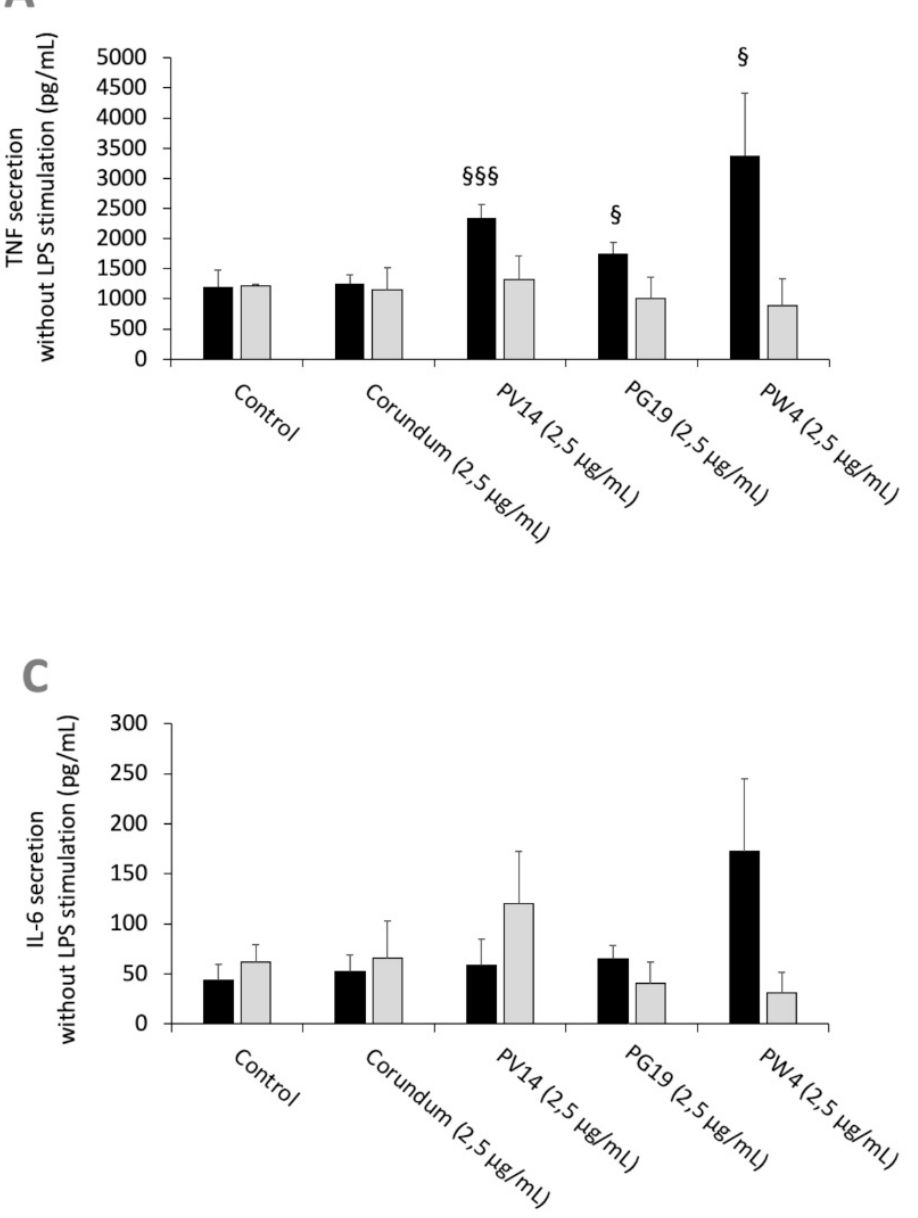
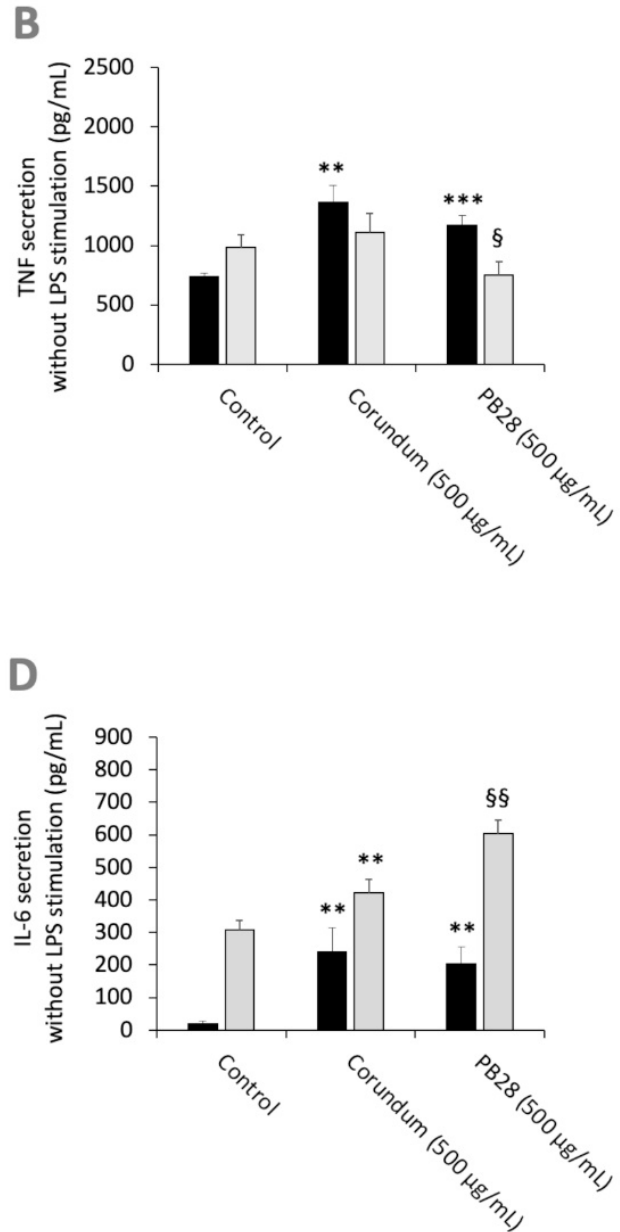

Figure 6 - Cytokine secretion without LPS stimulation.

Black bars: acute exposure (24 hours). Grey bars: exposure for 24 hours followed by a 3-day post-exposure recovery period. Panel A: TNF secretion. Conditions with $2.5 \mu \mathrm{g} / \mathrm{ml}$ of particle suspension. Panel B: TNF secretion. Conditions with $500 \mu \mathrm{g} / \mathrm{ml}$ of particle suspension. Panel C: IL-6 secretion. Conditions with $2.5 \mu \mathrm{g} / \mathrm{ml}$ of particle suspension. Panel D: IL-6 secretion. Condition with $500 \mu \mathrm{g} / \mathrm{ml}$ of particle suspension. Significance of symbols: * different from 
negative control only; $\S$ : different from both negative and corundum controls. Number of symbols: $1: p<0.05 ; 2: p<0.01 ; 3: p<0.001$.

After LPS stimulation and under acute exposure, IL-6 secretion (Figures 6C and 6D) remained unchanged for all the pigments tested in comparison to their controls. Conversely, under recovery exposure, the results showed a sharp drop in the secretion of IL-6 for PV14 $(2.5 \mu \mathrm{g} / \mathrm{mL})$ $(6079 \mathrm{pg} / \mathrm{mL})$, PG19 $(2.5 \mu \mathrm{g} / \mathrm{mL})(4,874 \mathrm{pg} / \mathrm{mL})$ and PW4 $(2.5 \mu \mathrm{g} / \mathrm{mL})(3,108 \mathrm{pg} / \mathrm{mL})$ in comparison to control without treatment $(12,334 \mathrm{pg} / \mathrm{mL})$ and corundum control $(2.5 \mu \mathrm{g} / \mathrm{mL})(14,250$ $\mathrm{pg} / \mathrm{mL})$. A significant decrease in IL-6 was also observed for PB28 $(9,704 \mathrm{pg} / \mathrm{mL})$ but only in comparison to control without treatment $(22,870 \mathrm{pg} / \mathrm{mL})$. Indeed, a slight decrease was also observed for corundum $(500 \mu \mathrm{g} / \mathrm{mL})(16,691 \mathrm{pg} / \mathrm{mL})$. Thus, for PB28 $(500 \mu \mathrm{g} / \mathrm{mL})$, the decrease was mainly due to the high concentration of particles and was not material-dependent. The results in Figures 6A and 6B show that under acute exposure and with LPS stimulation, no significant decrease in TNF secretion was observed for PV14 $(2.5 \mu \mathrm{g} / \mathrm{mL})$, PW4 $(2.5 \mu \mathrm{g} / \mathrm{mL})$, and PB28 $(500 \mu \mathrm{g} / \mathrm{mL})$. However, a significant increase was observed for PG19 $(2.5 \mu \mathrm{g} / \mathrm{mL})$ $(11,6296 \mathrm{pg} / \mathrm{mL}$ instead of $65,810 \mathrm{pg} / \mathrm{mL}$ and $79,474 \mathrm{pg} / \mathrm{mL}$ for control without treatment and control corundum $2.5 \mathrm{pg} / \mathrm{mL}$ ). Under recovery exposure, a sharp drop was observed (as in the case of IL-6 secretion). Indeed, for PV14, PG19, and PW4 $(2.5 \mu \mathrm{g} / \mathrm{mL})$, the concentration was $7,439 \mathrm{pg} / \mathrm{mL}, 13,887 \mathrm{pg} / \mathrm{mL}$ and $10,180 \mathrm{pg} / \mathrm{mL}$, respectively, while for control without treatment and corundum $(2.5 \mu \mathrm{g} / \mathrm{mL})$, the concentration in TNF was $47,920 \mathrm{pg} / \mathrm{mL}$ and 53,374 $\mathrm{pg} / \mathrm{mL}$, respectively. In the case of PB28, the decline $(1,796 \mathrm{pg} / \mathrm{mL})$ was more drastic than in the case of the other pigments in comparison to controls without treatment $(32,935 \mathrm{pg} / \mathrm{mL})$ and corundum $(500 \mu \mathrm{g} / \mathrm{mL})(26,824 \mathrm{pg} / \mathrm{mL})$.

In the case of PB28, the decrease was amplified by the high concentration of particles because a significant decrease was also observed in the case of corundum $(500 \mu \mathrm{g} / \mathrm{mL})$ in comparison to control without treatment.

A

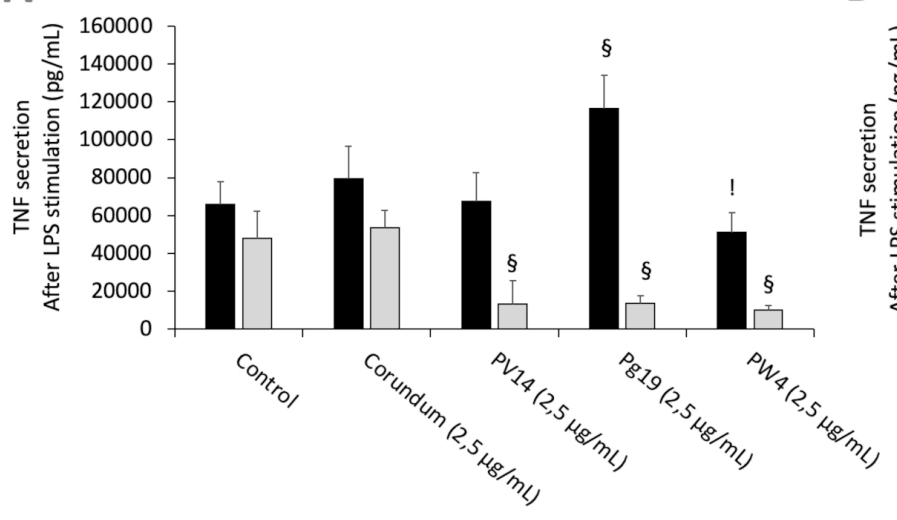

B

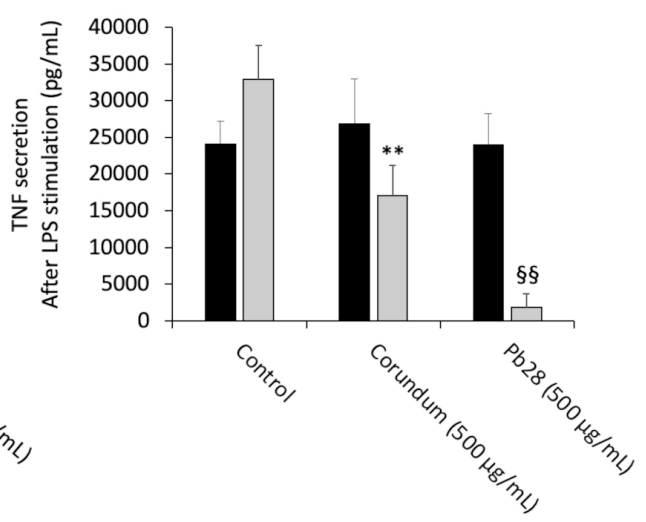

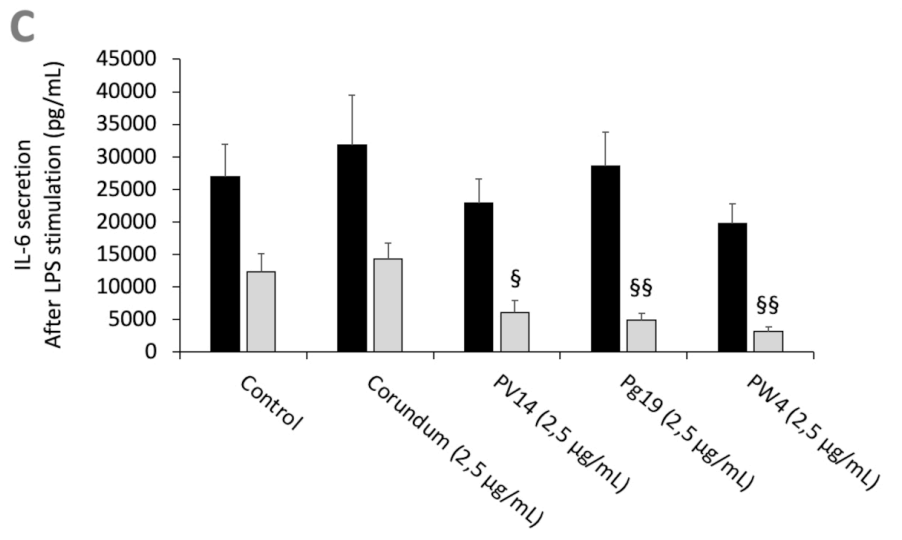

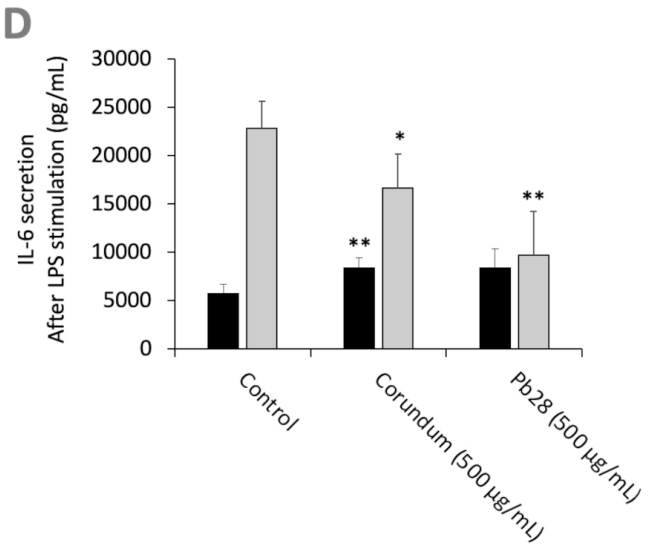


Figure 7 - Cytokine secretion after LPS stimulation.

Black bars: acute exposure (24 hours). Grey bars: exposure for 24 hours followed by a 3-day post-exposure recovery period. Panel A: TNF secretion. Conditions with $2.5 \mu \mathrm{g} / \mathrm{ml}$ of particle suspension. Panel B: TNF secretion. Conditions with $500 \mu \mathrm{g} / \mathrm{ml}$ of particle suspension. Panel C: IL-6 secretion. Conditions with $2.5 \mu \mathrm{g} / \mathrm{ml}$ of particle suspension. Panel D: IL-6 secretion. Condition with $500 \mu \mathrm{g} / \mathrm{ml}$ of particle suspension. Significance of symbols: *: different from negative control only; $\S$ : different from both negative and corundum controls; !: different from corundum control only. Number of symbols: $1: p<0.05 ; 2: p<0.01 ; 3: p<0.001$.

\subsection{Modulation of CD11b cell surface marker}

In order to know if pigments induced changes to the profiles of macrophages, we screened CD11b (Figures 8A and 8B), an integrin classically associated with macrophages and dendritic cells, and which contributes to cell adhesion and immunological tolerance. We thus investigated the proportion of cells becoming negative for the presence of $\mathrm{CD} 11 \mathrm{~b}$ at their surface. The results in Figure 8A showed that, under acute exposure, there was no change in the presence of CD11b at the surface of cells in the presence of PV14 $(2.5 \mu \mathrm{g} / \mathrm{ml})$, PG19 $(2.5 \mu \mathrm{g} / \mathrm{ml})$, and PW4 (2.5 $\mu \mathrm{g} / \mathrm{mL}$ ) in comparison to control without treatment. A significant increase in CD11b-negative cells $(19 \%)$ was observed for PG19 $(2.5 \mu \mathrm{g} / \mathrm{mL})$ in comparison to corundum control $(2.5$ $\mu \mathrm{g} / \mathrm{mL})(15 \%)$. However, we observed a slightly significant increase in CD11b-negative cells with a higher concentration of corundum $(500 \mu \mathrm{g} / \mathrm{ml})(16 \%)$ in comparison to control without treatment $(11 \%)$ (Figure 8B). Moreover, the percentage of CD11b-negative cells increased dramatically in the case of PB28 $(500 \mu \mathrm{g} / \mathrm{ml})$ to reach $62 \%$ (Figure $8 \mathrm{~B}$ ).

This increase in the proportion of CD11b-negative cells was observed at the end of the recovery period, for both the high concentration of corundum and PB28 (65\% of CD11b-negative cells in comparison to controls without treatment $(3 \%)$ and corundum $(500 \mu \mathrm{g} / \mathrm{mL})(8 \%)$. This suggests that PB28 has a highly sustained effect (Figure 8B). Moreover, the increase became significant after recovery exposure in the case of the cells exposed to PG19 or PW4 (14 and $15 \%$ of CD11b negative cells instead of 10 or $12 \%$ for controls $)$. PV14 $(2.5 \mu \mathrm{g} / \mathrm{mL})$ could have a small effect compared to the negative control, but not to the matched corundum control (Figure 8A). Thus, even if the effect was smaller than in the case of PB28 $(500 \mu \mathrm{g} / \mathrm{mL})$, the results suggested that PG19 $(2.5 \mu \mathrm{g} / \mathrm{mL})$ and PW4 $(2.5 \mu \mathrm{g} / \mathrm{mL})$ had a slight but significant delayed effect.

A

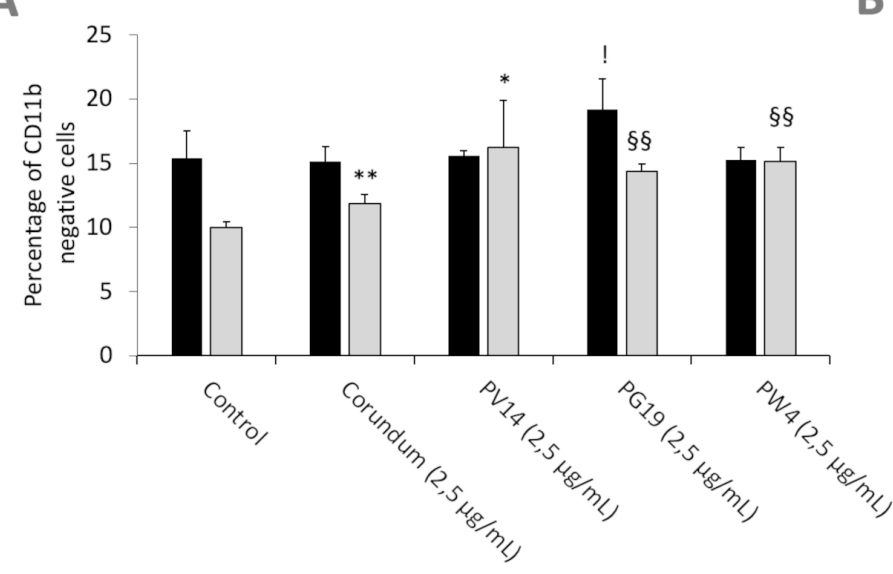

B

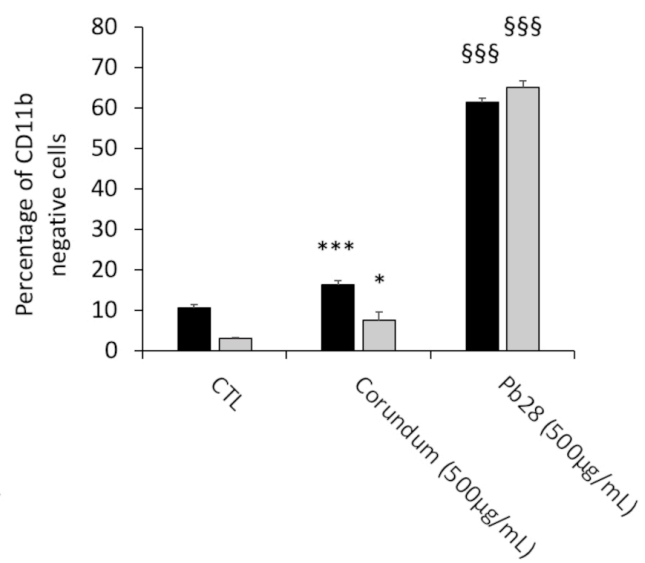

Figure 8-CD11b cell surface marking. 
Black bars: acute exposure (24 hours). Grey bars: exposure for 24 hours followed by a3-day post-exposure recovery period. Panel A: percentage of CDIlb-cells in comparison to unlabeled control cells. Conditions with $2.5 \mu \mathrm{g} / \mathrm{ml}$ of particle suspension. Panel B: percentage of CD11 b-cells in comparison to unlabeled control cells. Conditions with $500 \mu \mathrm{g} / \mathrm{ml}$ of particle suspension. Conditions with $500 \mu \mathrm{g} / \mathrm{ml}$ of particle suspension. Significance of symbols: *: different from negative control only; $\S$ : different from both negative and corundum controls; !: different from corundum control only. Number of symbols: $1: p<0.05 ; 2: p<0.01 ; 3: p<0.001$.

\subsection{Genotoxicity}

As cobalt is known to be genotoxic [28], we investigated this hypothesis and tested it via a comet assay. The results presented in Figure 10 showed that neither corundum nor the pigments had any affect at low concentrations $(2.5 \mu \mathrm{g} / \mathrm{ml})$, whether immediately after exposure or after the recovery period. However, a significant increase in DNA damage was observed immediately after exposure to high concentrations of particles (either corundum or PB28). The effect disappeared at the end of the recovery period in the case of corundum, but not in the case of PB28 where a sustained effect was detected, even though it lost intensity after recovery. PW4 was not tested because the genotoxicity of zinc oxide on macrophages has already been documented $[35,47]$. The result showed that the concentration $\leq 3.5$ or $4 \mu \mathrm{g} / \mathrm{mL}$ in ZNO nanoparticles did not induce DNA damage to macrophages.

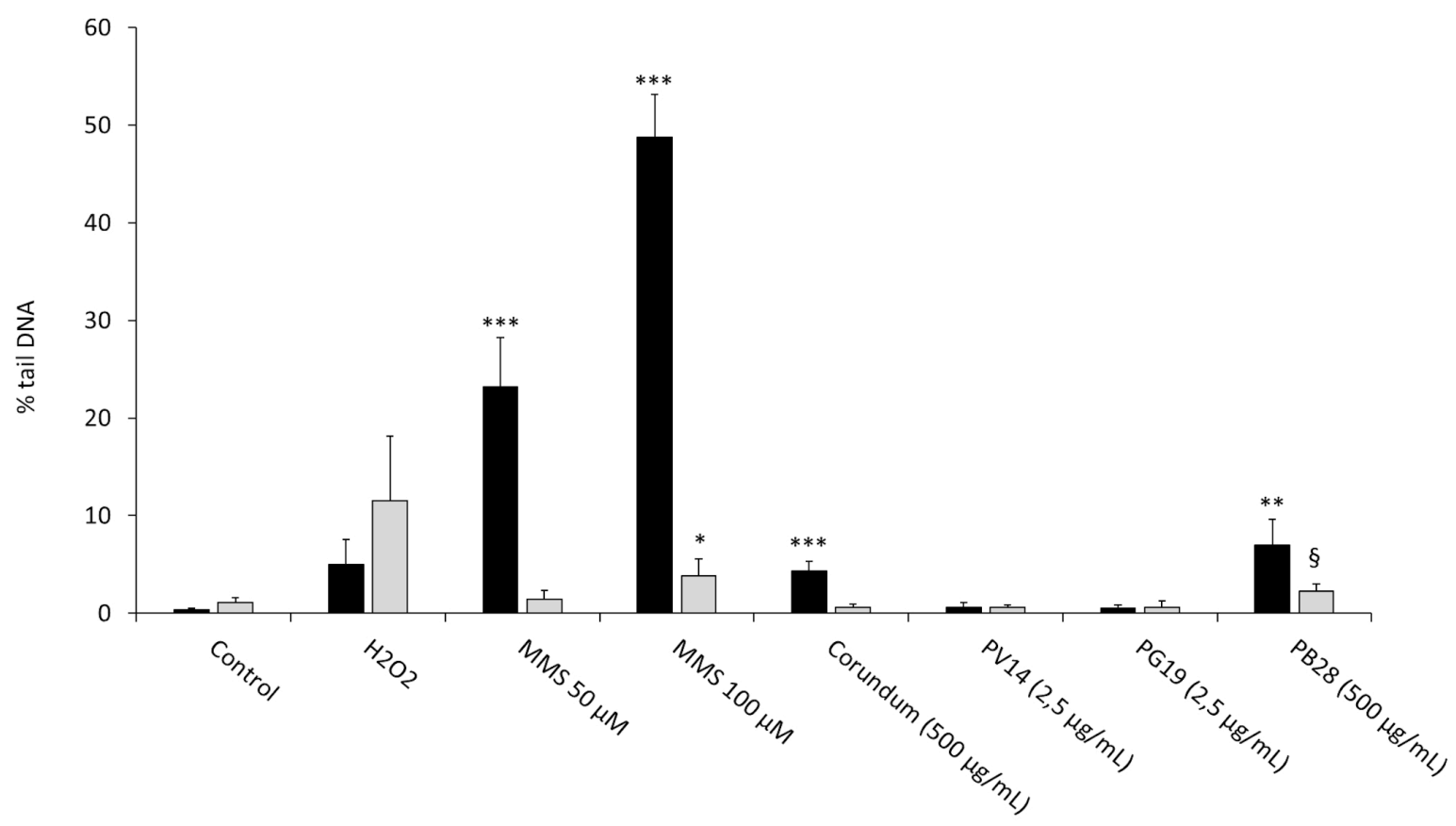

Figure 9 - Genotoxicity as determined by a comet assay.

Black bars: acute exposure (24 hours). Grey bars: exposure for 24 hours followed by a 3-day post-exposure recovery period. The percentage of DNA in the comet tail is measured as an indicator of the extent of damage to DNA. Methyl methanesulfonate (MMS) and hydrogen peroxide are used as positive controls. Significance of symbols: *: different from negative control only; : different from both negative and corundum controls $500 \mu \mathrm{g} / \mathrm{ml}$. Number of symbols: $1: p<0.05 ; 2: p<0.01 ; 3: p<0.001$.

\section{Discussion}


In any nanotoxicology context, the first question to be addressed is the relevance of the dose to be tested. For tattoos, the injected dose of pigments is reported to be in between 0.5 and 0.9 $\mathrm{mg} / \mathrm{cm} 2$, with an estimated mean of $2.5 \mathrm{mg} / \mathrm{cm} 2$ [9]. If it is assumed that all of these pigments are collected by dermal macrophages $[14,15]$, then this surface dose can be transposed to the pure macrophage culture. When transposed to a 12-well plate with $1 \mathrm{ml}$ of culture medium per well and a culture area of $3.8 \mathrm{~cm} 2$, this amount to a dose close to $9.5 \mathrm{mg} / \mathrm{ml}$ of pigments. Metal analyses of tattoo inks have suggested that they often contain a mixture of pigments [24], so that the total pigment dose cannot be considered to be composed of only one pigment. But even considering this dilution phenomenon, the doses used in the present study cannot be considered to be exaggerated.

Because tattoo inks are poorly regulated, their composition under the same trade name may evolve over time. In this respect, the comparison of the metals contained in tattoo inks between 2009 and 2020 [24,25] shows a reduction in toxic metals such as cobalt for example. Despite this positive trend, it should not be forgotten that data may be lacking regarding the people who were tattooed in the early 2000s, and therefore, regarding the potential long-term effects of these pigments. Thus, the relevance of examining the effects of cobalt pigments on macrophages cannot be underestimated. Even though they are often more expensive than organic pigments, mineral pigments show a high resistance to light, and degrade only by releasing their constituent metal ions, contrary to organic pigments that can have complex degradation pathways (e.g., in $[48,49])$.

With the above considerations in mind, we decided to investigate the responses of macrophages to three different cobalt-based pigments, and one zinc-based pigment which served as a comparison for PG19. Indeed, the results of ICP-AES showed the presence of a high quantity of zinc besides cobalt for PG19. Their toxicity is clearly split between toxic pigments (Pigment Violet 14, Pigment Green 19, and Pigment White 4, and low-toxicity pigments (Pigment Blue 28 ) leading to a very high LD20 concentration. As the latter could be used at high concentrations (i.e., close to $1 \mathrm{mg} / \mathrm{ml}$ ), the possibility of macrophage being overloaded [50,51] could not be ruled out. In any case, compared to the untreated negative control, the onset of phagocytosis due to the presence of particulate material is likely to induce changes to macrophage physiology, which should not be mistaken for specific effects induced by the cobalt pigments. We thus used the negative corundum control [52], at both low and high concentrations, in order to take these potential effects into account.

Furthermore, as the adverse effects of cobalt and/or zinc can be expected to occur via a progressive release in ionic form, we decided to take this parameter into account by using an exposure-recovery scheme, in which the degradation of the pigments inside the macrophage is likely to start to occur even for poorly-degradable pigments. For more degradable pigments, this degradation may occur even during a short exposure period.

Indeed, one of the reasons for the low toxicity of pigments resides in their very low solubility in water, and thus, in biological media, so that no release of toxic components should occur. Mineral pigments known to be toxic, such as lead white (basic lead carbonate) and vermillion (mercuric sulfide) dissolve slowly in biological media, leading to a release of toxic heavy metal ions. In fact, biological media are more complex than plain water. Assuming that pigment particles end up, at least in part, in macrophages' phagolysosomes, these particles will encounter a mildly acidic medium ( $\mathrm{pH} \mathrm{5)}$ containing a high concentration of proteins (comprising enzymes) that bind many metal ions with high affinity. This may explain why water-insoluble pigments may prove soluble to some extent in biological media. This description of the biological media also suggests that pigment biosolubility will depend on the structure of each pigment. The results on cobalt pigments show a clear correlation between the results obtained in strongly acidic mineralization and the results obtained in vivo. Pigments and minerals that are poorly 
soluble in acidic media, such as corundum or PB28, are also less easily dissolved in cells $(0.01 \%$ after 24 hours) while pigments that dissolve more easily in acidic media, such as PV14, also dissolve more easily in cells (ca. 2\% dissolved in cells after 24 hours). This is reflected in the toxicity of the pigments, as more soluble pigments show a higher toxicity than poorly soluble pigments (LD20 of $2.5 \mu \mathrm{g} / \mathrm{ml}$ for PV14 compared to $500 \mu \mathrm{g} / \mathrm{ml}$ for PB28). The data are more difficult to interpret for PG19, as it contains too little cobalt to distinguish it from the background levels.

Because of this difference in solubility, the biological effects of the pigments are likely to be a mixture of purely nano- or microparticulate effects along with effects linked to ion release. This is why we systematically included corundum as a particulate control. Indeed, it has been shown to exhibit minimal toxicity and no pro-inflammatory effects, which makes it of great interest to be studied in macrophage biology [52].

One of the effects that can be expected to be dependent on particle concentration is phagocytosis, which is linked to the well-known overload effect [50,51]. However, our results showed that phagocytosis was also impacted by a low quantity of internalized particles. This slight decrease is probably not due to an overload effect but can be explained by the release of soluble cobalt or zinc ions via the lysosomal or phagolysosomal process. At a higher concentration, we observed a correlation between the overload effect and this model, this is because a higher impact was detected in the presence of a high quantity of internalized particle for both corundum and PB28 (under acute exposure). Interestingly enough, the highly-corundum loaded cells recovered a normal phagocytic activity after a few days while the cells exposed to an equal concentration of a cobalt-containing pigment with the same crystalline structure (spinel) did not, which clearly shows that cobalt has a delayed effect. This persisting effect was also observed for a lower concentration of pigment, but only for those composed of zinc, such as PG19 and PW4, suggesting a specific effect of zinc.

All particles also induced a weak pro-inflammatory effect. This is also true in the case of corundum (at high concentration), while this effect had not been detected previously in an indirect assay, but in serum-free culture conditions [52]. These results were first observed with a NO assay and already revealed an overall persistent pro-inflammatory effect of PV14, PG19 and PW4. Thus, the engulfment of cobalt and/or zinc (nano)particles present in some pigments could induce a slight, long-term inflammation. No synergistic effect was identified in the case of a mixture of zinc and cobalt. Indeed, the intrinsic long-term pro-inflammatory effect was similar between PV14, PG19, and PW4. On the contrary, the mixture of cobalt and aluminum did not induce persisting effect at high quantity while corundum (which is composed of aluminum oxide) induced a persisting effect at high concentration. For TNF, this effect was essentially transient. However, a decrease was noted after recovery exposure in the case of the cells exposed to PB28 at high concentration. This result is in line with those observed via the NO assay and the reason is probably linked to the presence of soluble cobalt + aluminum ions release in cells.

This scheme was not observed for interleukin 6: no significant sustained stimulation was observed except for the higher concentration of particles $(500 \mu \mathrm{g} / \mathrm{mL}$ for corundum and PB28). Like phagocytosis, the intrinsic transient and persisting effects of (nano)particles on IL-6 are due to an overload of internalized materials, but it can also be aggravated by the long-term release of cobalt ions after a high quantity of PB28 has been engulfed.

To go further into the question of the intrinsic effects of cobalt-containing pigments on macrophages, we also investigated their genotoxicity. Interestingly, the highly soluble and toxic pigments did not show a detectable genotoxicity, even though the amount of intracellular soluble cobalt is well above the concentration used as soluble cobalt on total leukocytes (35-65 fg $\mathrm{Co} /$ cell in this work, based on a protein content of $300 \mathrm{pg}$ protein/cell [53], compared to the 5$8 \mathrm{fg} \mathrm{Co/cell} \mathrm{used} \mathrm{on} \mathrm{leukocytes)} \mathrm{[29].} \mathrm{This} \mathrm{result} \mathrm{is} \mathrm{in} \mathrm{line} \mathrm{with} \mathrm{the} \mathrm{established} \mathrm{resistance} \mathrm{of}$ 
macrophages to genotoxicity, as opposed to lymphocytes, which account for the vast majority of mononuclear leukocytes, and are highly sensitive to genotoxic stresses. Interestingly, a genotoxic effect was observed with high concentrations of particles, whether in the case of corundum or PB28. This effect was transient for corundum but sustained for PB28. This effect may be correlated with either the release of soluble cobalt and aluminum (Table 2) or an intrinsic effect of some insoluble particles (in this particular case, an alloy of aluminum and cobalt), as described in the case of titanium dioxide (reviewed in [54]). Indeed, an overload of particles in cells could disturb antioxidative and DNA repair processes [55].

In addition to these effects, we investigated other effects of cobalt-containing pigments on the functionality of macrophages. We first investigated the response to an LPS challenge which would mimic an antibacterial response. We did not observe any significant change to the secretion of IL-6. Regarding the secretion of TNF, we only observed a moderate increase for PG19 and only immediately after exposure. The most striking fact is the general decrease in the responses of TNF and IL- 6 after the recovery period. Coupled with the effects on phagocytosis, these results suggest that macrophages become slightly less efficient in fighting a bacterial infection when loaded with cobalt- and/or zinc-containing pigments. Corundum also induced a decrease of TNF and IL-6 (though lower than PB28) and only at a high concentration (500 $\mu \mathrm{g} / \mathrm{mL}$ ). Thus, for PB28, an overload effect is probably combined with the dissolution of the alloy of cobalt and aluminum. This sort of effect was not observed in the case of macrophages treated with amorphous silica [39]. It was observed, however, in the case of macrophages treated with silver nanoparticles [38], which also release toxic metallic ions during the recovery phase. When compared to results obtained under chronic exposure to silver nanoparticles [56], the results of this study on cobalt and/or zinc-containing pigments suggest that this decrease in performance may last over time, a fact which is to be taken into account in the perspective of the long-term effects of tattoos.

Finally, we also tested CD11b, a cell-surface marker important for the good functioning of macrophages. Indeed, CD11b is also part of the complement receptor 3, and, as such, plays a role in phagocytosis for complement-opsonized pathogens [57]. Thus, CD11b-negative cells are likely to be impaired, and thus, less efficient for the elimination of pathogens.

Last but not least, $\mathrm{CD} 11 \mathrm{~b}$ also plays a role in immune regulation as a negative regulator of immune responses [58,59]. Thus, the absence of CD11b results in a higher T-cell activation [60] and may result in a reduction of tolerance and over reactive inflammatory response [61]. Moreover, the activation of CD11b, which is linked to the anti-tumor immune response [62], will be impossible in CD11b-negative cells, and may contribute to a lower anti-tumoral activity. Overall, the macrophages treated with zinc and cobalt-containing pigments appear less efficient against pathogens, less efficient against tumors and they also seem to have a more (basal) proinflammatory phenotype. Of course, the effects are likely to be moderate, and it can be argued that the effects that we detected over a few days may normalize over time. However, our results on the persistence of these effects, coupled with the now-established capture-death-recapture macrophage cycle following the injection of tattoo pigments $[15,16]$, point towards a self-sustaining process which alters macrophages on the long term.

Although mineral pigments (such as cobalt or zinc nano- and microparticles) are now seldom used in tattoo inks, the fact that people may have received such pigments in the past [25] as well as the possibility that other pigments may also alter the functions of macrophages, possibly via completely different mechanisms, point to the need for more research in the field of sustained/delayed effects of pigments. 
Moreover, even if the results are not exactly the same as those obtained in this paper, other articles [63] confirm that the presence of cobalt ions (and also of other metals such as copper) induces changes to the functionalities of macrophages, in particular their pro- or antiinflammatory profile. The differences observed are probably related to the different form of the cobalt elements, since in our work, we used particulate pigments as metal sources.

\section{Conclusion}

In conclusion, the pigments tested contain nano-objects, and not only microparticles. Overall, looking at the data regarding the secretion of NO, IL-6 and TNF, the pigments tested seem to have a moderate intrinsic pro-inflammatory effect. This effect, however, may persist over time. Concerning the body's defense mechanisms, the macrophages which have internalized the cobalt- or zinc-based pigments have a lower ability to respond to a bacterial infection (e.g., skin infection). Indeed, the phagocytic capacity of macrophages and their capacity to respond to inflammatory stimuli decrease, and this effect is persistent. This idea is reinforced by the additional presence of CD11b-negative cells. Following this study, the question arises as to whether the inks containing cobalt and/or zinc micro- and nano-objects are safe or not. It is legitimate to wonder if they can generate localized or generalized alterations of immunoregulation and weaken the body's defense mechanisms against bacterial pathogens and their ability to recognize cancer cells. The effects which were observed seem to have been reinforced by overload effects (for high concentrations of pigments), and are proportionally linked to the release of free ions during the dissolution in the phagolysosomes.

\section{Supplementary data:}




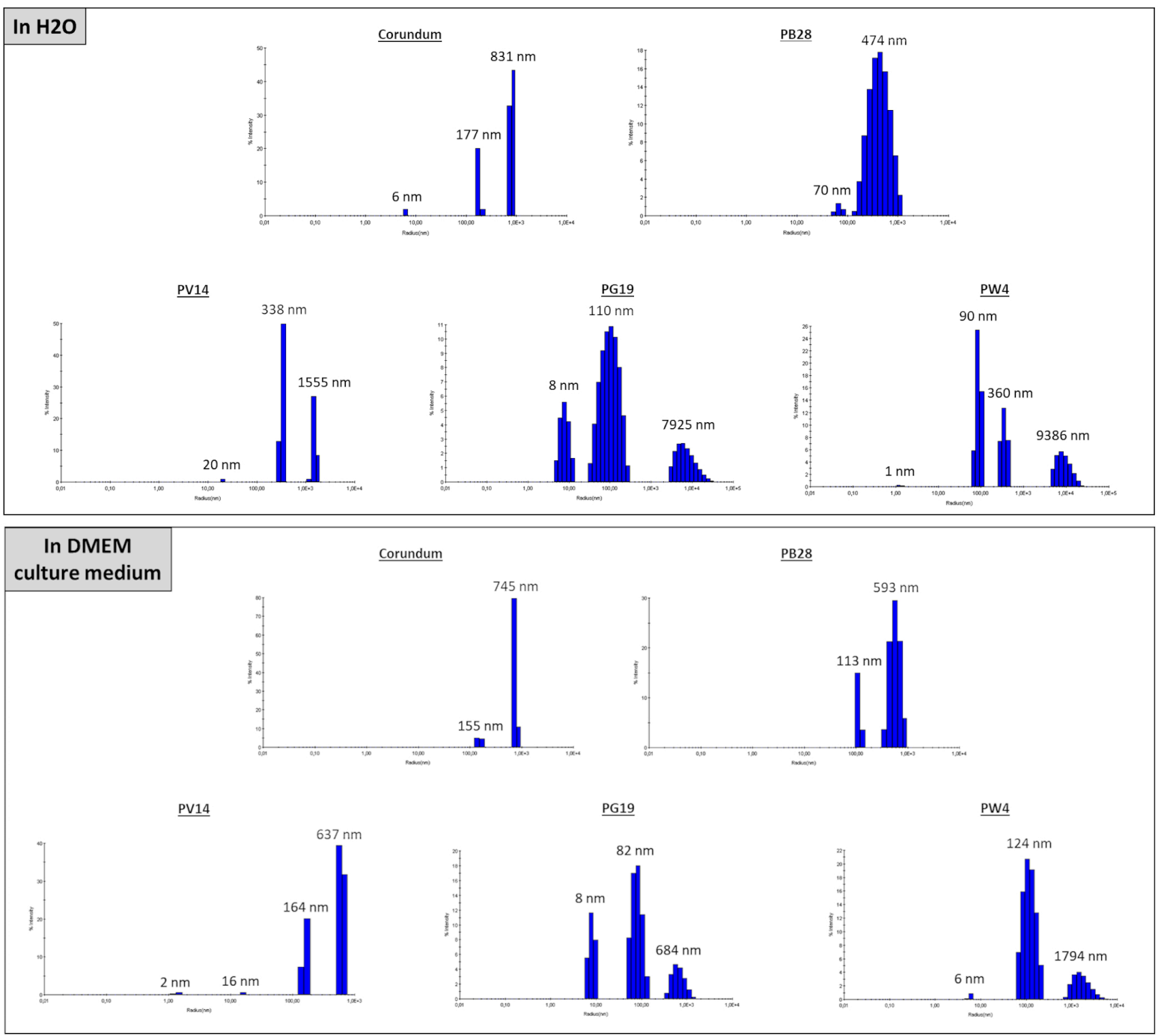

Supplementary data 1 - Example of hydrodynamic diameter measurement (screen print of raw data) by $\mathrm{DLS}$ in $\mathrm{H}_{2} \mathrm{O}$ and DMEM culture medium.

\section{Acknowledgements:}

The authors would like to thank Maxime Petit (PRAG English teacher), Université Toulouse 1Capitole for proofreading the manuscript.

\section{Author contributions:}

JD and BD performed experiments on the functional effects of pigments on macrophages and ICP-AES measurements. MD and MC performed the genotoxicity assays. JP trained the experimenters at the ICP-AES. TR analyzed the ICP-AES results. DF performed TEM microscopy visualization. VCF acquired and analyzed flow cytometry experiments. BD and TR supervised the overall research. The manuscript was written by TR, BD, and to a lesser extent, JD. All co-authors approved the final version of the manuscript.

\section{Funding:}


This project received funding from GRAL, a program from the Chemistry Biology Health (CBH) Graduate School of University Grenoble Alpes (ANR-17-EURE-0003).

This work used the EM facility at the Grenoble Instruct-ERIC Center (ISBG; UAR 3518 CNRS CEA-UGA-EMBL) with support from the French Infrastructure for Integrated Structur-al Biology (FRISBI; ANR-10-INSB-05-02) and GRAL, a project of the University Grenoble Alpes graduate school (Ecoles Universitaires de Recherche) CBH-EUR-GS (ANR-17-EURE-0003). The IBS Electron Microscope facility is supported by the Auvergne Rhône-Alpes Région, the Fonds Feder, the Fondation pour la Recherche Médicale and GIS-IBiSA.

\section{Conflict of interest:}

The authors declare that the research was conducted in the absence of any commercial or financial relationships that could be construed as a potential conflict of interest.

\section{References:}

1. Deter-Wolf, A. The Material Culture and Middle Stone Age Origins of Ancient Tattooing. In Tattoos and Body Modifications in Antiquity. Proceedings of the sessions at the EAA annual meetings in The Hague and Oslo, 2010/11; Zurich Studies in Archaeology; 2013; pp. 15-26.

2. $\quad$ Dorfer, L.; Moser, M.; Bahr, F.; Spindler, K.; Egarter-Vigl, E.; Giullén, S.; Dohr, G.; Kenner, T. A Medical Report from the Stone Age? Lancet 1999, 354, 1023-1025, doi:10.1016/S0140-6736(98)12242-0.

3. Pabst, M.A.; Letofsky-Papst, I.; Moser, M.; Spindler, K.; Bock, E.; Wilhelm, P.; Leopold Dorfer, M.D.; Geigl, J.B.; Auer, M.; Speicher, M.R.; et al. Different Staining Substances Were Used in Decorative and Therapeutic Tattoos in a 1000-Year-Old Peruvian Mummy. Journal of Archaeological Science 2010, 37, 3256-3262, doi:10.1016/j.jas.2010.07.026.

4. Maarouf, M.; Saberian, C.; Segal, R.J.; Shi, V.Y. A New Era For Tattoos, with New Potential Complications. J Clin Aesthet Dermatol 2019, 12, 37-38.

5. Paprottka, F.J.; Krezdorn, N.; Narwan, M.; Turk, M.; Sorg, H.; Noah, E.M.; Hebebrand, D. Trendy Tattoos-Maybe a Serious Health Risk? Aesthetic Plast Surg 2018, 42, 310 321, doi:10.1007/s00266-017-1002-0.

6. Jacob, C.I. Tattoo-Associated Dermatoses: A Case Report and Review of the Literature. Dermatol Surg 2002, 28, 962-965, doi:10.1046/j.1524-4725.2002.02066.x.

7. Forbat, E.; Al-Niaimi, F. Patterns of Reactions to Red Pigment Tattoo and Treatment Methods. Dermatol Ther (Heidelb) 2016, 6, 13-23, doi:10.1007/s13555-016-0104-y.

8. Lerche, C.M.; Heerfordt, I.M.; Serup, J.; Poulsen, T.; Wulf, H.C. Red Tattoos, Ultraviolet Radiation and Skin Cancer in Mice. Exp Dermatol 2017, 26, 1091-1096, doi:10.1111/exd.13383.

9. Baumler, W. Absorption, Distribution, Metabolism and Excretion of Tattoo Colorants and Ingredients in Mouse and Man: The Known and the Unknown. In Current Problems in Dermatology; Serup, J., Kluger, N., Baumler, W., Eds.; S. Karger AG, 2015; Vol. 48, pp. 176-184 ISBN 978-3-318-02776-1.

10. Regensburger, J.; Lehner, K.; Maisch, T.; Vasold, R.; Santarelli, F.; Engel, E.; Gollmer, A.; König, B.; Landthaler, M.; Bäumler, W. Tattoo Inks Contain Polycyclic Aromatic Hydrocarbons That Additionally Generate Deleterious Singlet Oxygen. Exp Dermatol 2010, 19, e275-281, doi:10.1111/j.1600-0625.2010.01068.x.

11. Kluger, N. Cutaneous Complications Related to Permanent Decorative Tattooing. Expert Rev Clin Immunol 2010, 6, 363-371, doi:10.1586/eci.10.10. 
12. Wenzel, S.M.; Rittmann, I.; Landthaler, M.; Bäumler, W. Adverse Reactions after Tattooing: Review of the Literature and Comparison to Results of a Survey. Dermatology 2013, 226, 138-147, doi:10.1159/000346943.

13. Plum, L.M.; Rink, L.; Haase, H. The Essential Toxin: Impact of Zinc on Human Health. IJERPH 2010, 7, 1342-1365, doi:10.3390/ijerph7041342.

14. Kluegl, I.; Hiller, K.-A.; Landthaler, M.; Baeumler, W. Incidence of Health Problems Associated with Tattooed Skin: A Nation-Wide Survey in German-Speaking Countries. Dermatology 2010, 221, 43-50, doi:10.1159/000292627.

15. Baranska, A.; Shawket, A.; Jouve, M.; Baratin, M.; Malosse, C.; Voluzan, O.; Vu Manh, T.-P.; Fiore, F.; Bajénoff, M.; Benaroch, P.; et al. Unveiling Skin Macrophage Dynamics Explains Both Tattoo Persistence and Strenuous Removal. J Exp Med 2018, 215, 11151133, doi:10.1084/jem.20171608.

16. Collin, M. Death, Eaters, and Dark Marks. J Exp Med 2018, 215, 1005-1006, doi:10.1084/jem.20180311.

17. Chen, G.Y.; Nuñez, G. Sterile Inflammation: Sensing and Reacting to Damage. Nat Rev Immunol 2010, 10, 826-837, doi:10.1038/nri2873.

18. Navegantes, K.C.; de Souza Gomes, R.; Pereira, P.A.T.; Czaikoski, P.G.; Azevedo, C.H.M.; Monteiro, M.C. Immune Modulation of Some Autoimmune Diseases: The Critical Role of Macrophages and Neutrophils in the Innate and Adaptive Immunity. $J$ Transl Med 2017, 15, 36, doi:10.1186/s12967-017-1141-8.

19. Schreiver, I.; Hesse, B.; Seim, C.; Castillo-Michel, H.; Villanova, J.; Laux, P.; Dreiack, N.; Penning, R.; Tucoulou, R.; Cotte, M.; et al. Synchrotron-Based v-XRF Mapping and $\mu$-FTIR Microscopy Enable to Look into the Fate and Effects of Tattoo Pigments in Human Skin. Sci Rep 2017, 7, 11395, doi:10.1038/s41598-017-11721-z.

20. Nopajaroonsri, C.; Simon, G.T. Phagocytosis of Colloidal Carbon in a Lymph Node. Am $J$ Pathol 1971, 65, 25-42.

21. Engel, E.; Vasold, R.; Santarelli, F.; Maisch, T.; Gopee, N.V.; Howard, P.C.; Landthaler, M.; Bäumler, W. Tattooing of Skin Results in Transportation and Light-Induced Decomposition of Tattoo Pigments--a First Quantification in Vivo Using a Mouse Model. Exp Dermatol 2010, 19, 54-60, doi:10.1111/j.1600-0625.2009.00925.x.

22. Lehner, K.; Santarelli, F.; Penning, R.; Vasold, R.; Engel, E.; Maisch, T.; Gastl, K.; König, B.; Landthaler, M.; Bäumler, W. The Decrease of Pigment Concentration in Red Tattooed Skin Years after Tattooing. J Eur Acad Dermatol Venereol 2011, 25, 13401345, doi:10.1111/j.1468-3083.2011.03987.x.

23. Khan, Z.; Combadière, C.; Authier, F.-J.; Itier, V.; Lux, F.; Exley, C.; Mahrouf-Yorgov, M.; Decrouy, X.; Moretto, P.; Tillement, O.; et al. Slow CCL2-Dependent Translocation of Biopersistent Particles from Muscle to Brain. BMC Med 2013, 11, 99, doi:10.1186/1741-7015-11-99.

24. Gherardi, R.K.; Eidi, H.; Crépeaux, G.; Authier, F.J.; Cadusseau, J. Biopersistence and Brain Translocation of Aluminum Adjuvants of Vaccines. Front Neurol 2015, 6, 4, doi:10.3389/fneur.2015.00004.

25. Forte, G.; Petrucci, F.; Cristaudo, A.; Bocca, B. Market Survey on Toxic Metals Contained in Tattoo Inks. Science of The Total Environment 2009, 407, 5997-6002, doi:10.1016/j.scitotenv.2009.08.034.

26. Battistini, B.; Petrucci, F.; De Angelis, I.; Failla, C.M.; Bocca, B. Quantitative Analysis of Metals and Metal-Based Nano- and Submicron-Particles in Tattoo Inks. Chemosphere 2020, 245, 125667, doi:10.1016/j.chemosphere.2019.125667.

27. Simonsen, L.O.; Harbak, H.; Bennekou, P. Cobalt Metabolism and Toxicology--a Brief Update. Sci Total Environ 2012, 432, 210-215, doi:10.1016/j.scitotenv.2012.06.009. 
28. Papageorgiou, I.; Brown, C.; Schins, R.; Singh, S.; Newson, R.; Davis, S.; Fisher, J.; Ingham, E.; Case, C.P. The Effect of Nano- and Micron-Sized Particles of CobaltChromium Alloy on Human Fibroblasts in Vitro. Biomaterials 2007, 28, 2946-2958, doi:10.1016/j.biomaterials.2007.02.034.

29. Colognato, R.; Bonelli, A.; Ponti, J.; Farina, M.; Bergamaschi, E.; Sabbioni, E.; Migliore, L. Comparative Genotoxicity of Cobalt Nanoparticles and Ions on Human Peripheral Leukocytes in Vitro. Mutagenesis 2008, 23, 377-382, doi:10.1093/mutage/gen024.

30. Kwon, Y.-M.; Xia, Z.; Glyn-Jones, S.; Beard, D.; Gill, H.S.; Murray, D.W. DoseDependent Cytotoxicity of Clinically Relevant Cobalt Nanoparticles and Ions on Macrophages in Vitro. Biomed Mater 2009, 4, 025018, doi:10.1088/17486041/4/2/025018.

31. Kumanto, M.; Paukkeri, E.-L.; Nieminen, R.; Moilanen, E. Cobalt(II) Chloride Modifies the Phenotype of Macrophage Activation. Basic Clin Pharmacol Toxicol 2017, 121, 98105, doi:10.1111/bcpt.12773.

32. Schuster, B.E.; Roszell, L.E.; Murr, L.E.; Ramirez, D.A.; Demaree, J.D.; Klotz, B.R.; Rosencrance, A.B.; Dennis, W.E.; Bao, W.; Perkins, E.J.; et al. In Vivo Corrosion, Tumor Outcome, and Microarray Gene Expression for Two Types of Muscle-Implanted Tungsten Alloys. Toxicology and Applied Pharmacology 2012, 265, 128-138, doi:10.1016/j.taap.2012.08.025.

33. Jarosz, M.; Olbert, M.; Wyszogrodzka, G.; Młyniec, K.; Librowski, T. Antioxidant and Anti-Inflammatory Effects of Zinc. Zinc-Dependent NF-KB Signaling. Inflammopharmacol 2017, 25, 11-24, doi:10.1007/s10787-017-0309-4.

34. Agnew, U.M.; Slesinger, T.L. Zinc Toxicity. In StatPearls; StatPearls Publishing: Treasure Island (FL), 2021.

35. Aude-Garcia, C.; Dalzon, B.; Ravanat, J.L.; Collin-Faure, V.; Diemer, H.; Strub, J.M.; Cianferani, S.; Van Dorsselaer, A.; Carriere, M.; Rabilloud, T. A Combined Proteomic and Targeted Analysis Unravels New Toxic Mechanisms for Zinc Oxide Nanoparticles in Macrophages. Journal of Proteomics 2016, 134, 174-185, doi:10.1016/j.jprot.2015.12.013.

36. Cho, W .-S.; Duffin, R.; Howie, S.E.; Scotton, C.J.; Wallace, W.A.; MacNee, W.; Bradley, M.; Megson, I.L.; Donaldson, K. Progressive Severe Lung Injury by Zinc Oxide Nanoparticles; the Role of Zn2+ Dissolution inside Lysosomes. Part Fibre Toxicol 2011, 8, 27, doi:10.1186/1743-8977-8-27.

37. Song, W.; Zhang, J.; Guo, J.; Zhang, J.; Ding, F.; Li, L.; Sun, Z. Role of the Dissolved Zinc Ion and Reactive Oxygen Species in Cytotoxicity of ZnO Nanoparticles.

Toxicology Letters 2010, 199, 389-397, doi:10.1016/j.toxlet.2010.10.003.

38. Dalzon, B.; Torres, A.; Diemer, H.; Ravanel, S.; Collin-Faure, V.; Pernet-Gallay, K.; Jouneau, P.-H.; Bourguignon, J.; Cianférani, S.; Carrière, M.; et al. How Reversible Are the Effects of Silver Nanoparticles on Macrophages? A Proteomic-Instructed View. Environmental Science: Nano 2019, 6, 3133-3157.

39. Torres, A.; Dalzon, B.; Collin-Faure, V.; Diemer, H.; Fenel, D.; Schoehn, G.; Cianférani, S.; Carrière, M.; Rabilloud, T. How Reversible Are the Effects of Fumed Silica on Macrophages? A Proteomics-Informed View. Nanomaterials (Basel) 2020, 10, 1939, doi:10.3390/nano10101939.

40. Dalzon, B.; Torres, A.; Devcic, J.; Fenel, D.; Sergent, J.-A.; Rabilloud, T. A Low-Serum Culture System for Prolonged in Vitro Toxicology Experiments on a Macrophage System. Front. Toxicol. 2021, 3, 780778, doi:10.3389/ftox.2021.780778. 
41. Rabilloud, T. Optimization of the Cydex Blue Assay: A One-Step Colorimetric Protein Assay Using Cyclodextrins and Compatible with Detergents and Reducers. PLoS One 2018, 13, e0195755.

42. Abel, G.; Szollosi, J.; Fachet, J. Phagocytosis of Fluorescent Latex Microbeads by Peritoneal Macrophages in Different Strains of Mice: A Flow Cytometric Study. Eur J Immunogenet 1991, 18, 239-245.

43. Triboulet, S.; Aude-Garcia, C.; Carriere, M.; Diemer, H.; Proamer, F.; Habert, A.; Chevallet, M.; Collin-Faure, V.; Strub, J.M.; Hanau, D.; et al. Molecular Responses of Mouse Macrophages to Copper and Copper Oxide Nanoparticles Inferred from Proteomic Analyses. Mol Cell Proteomics 2013, 12, 3108-3122.

44. Repetto, G.; del Peso, A.; Zurita, J.L. Neutral Red Uptake Assay for the Estimation of Cell Viability/Cytotoxicity. Nat Protoc 2008, 3, 1125-1131.

45. Armand, L.; Tarantini, A.; Beal, D.; Biola-Clier, M.; Bobyk, L.; Sorieul, S.; PernetGallay, K.; Marie-Desvergne, C.; Lynch, I.; Herlin-Boime, N.; et al. Long-Term Exposure of A549 Cells to Titanium Dioxide Nanoparticles Induces DNA Damage and Sensitizes Cells towards Genotoxic Agents. Nanotoxicology 2016, 10, 913-923, doi:10.3109/17435390.2016.1141338.

46. Kroll, A.; Pillukat, M.H.; Hahn, D.; Schnekenburger, J. Current in Vitro Methods in Nanoparticle Risk Assessment: Limitations and Challenges. Eur J Pharm Biopharm 2009, 72, 370-377, doi:10.1016/j.ejpb.2008.08.009.

47. Triboulet, S.; Aude-Garcia, C.; Armand, L.; Gerdil, A.; Diemer, H.; Proamer, F.; CollinFaure, V.; Habert, A.; Strub, J.M.; Hanau, D.; et al. Analysis of Cellular Responses of Macrophages to Zinc Ions and Zinc Oxide Nanoparticles: A Combined Targeted and Proteomic Approach. Nanoscale 2014, 6, 6102-6114.

48. Schreiver, I.; Hutzler, C.; Laux, P.; Berlien, H.-P.; Luch, A. Formation of Highly Toxic Hydrogen Cyanide upon Ruby Laser Irradiation of the Tattoo Pigment Phthalocyanine Blue. Sci Rep 2015, 5, 12915, doi:10.1038/srep12915.

49. Bauer, E.M.; Scibetta, E.V.; Cecchetti, D.; Piccirillo, S.; Antonaroli, S.; Sennato, S.; Cerasa, M.; Tagliatesta, P.; Carbone, M. Treatments of a Phthalocyanine-Based Green Ink for Tattoo Removal Purposes: Generation of Toxic Fragments and Potentially Harmful Morphologies. Arch Toxicol 2020, 94, 2359-2375, doi:10.1007/s00204-020-02790-7.

50. Oberdörster, G. Lung Particle Overload: Implications for Occupational Exposures to Particles. Regul Toxicol Pharmacol 1995, 21, 123-135, doi:10.1006/rtph.1995.1017.

51. Warheit, D.B.; Hansen, J.F.; Yuen, I.S.; Kelly, D.P.; Snajdr, S.I.; Hartsky, M.A. Inhalation of High Concentrations of Low Toxicity Dusts in Rats Results in Impaired Pulmonary Clearance Mechanisms and Persistent Inflammation. Toxicol Appl Pharmacol 1997, 145, 10-22, doi:10.1006/taap.1997.8102.

52. Wiemann, M.; Vennemann, A.; Sauer, U.G.; Wiench, K.; Ma-Hock, L.; Landsiedel, R. An in Vitro Alveolar Macrophage Assay for Predicting the Short-Term Inhalation Toxicity of Nanomaterials. J Nanobiotechnol 2016, 14, 16, doi:10.1186/s12951-016-0164-2.

53. Tsuboi, A.; Kurotsu, T.; Terasima, T. Changes in Protein Content per Cell during Growth of Mouse L Cells. Exp Cell Res 1976, 103, 257-261, doi:10.1016/0014-4827(76)90262-7.

54. Carriere, M.; Arnal, M.-E.; Douki, T. TiO2 Genotoxicity: An Update of the Results Published over the Last Six Years. Mutat Res 2020, 854-855, 503198, doi:10.1016/j.mrgentox.2020.503198.

55. Carriere, M.; Sauvaigo, S.; Douki, T.; Ravanat J.L. Impact of nanoparticles on DNA repair processes: current knowledge and working hypotheses. Mutagenesis 2017, 32,203-213, doi:10.1093/mutage/gew052.

56. Dalzon, B.; Aude-Garcia, C.; Diemer, H.; Bons, J.; Marie-Desvergne, C.; Pérard, J.; Dubosson, M.; Collin-Faure, V.; Carapito, C.; Cianférani, S.; et al. The Longer the Worse: A Combined Proteomic and Targeted Study of the Long-Term versus Short-Term Effects of Silver Nanoparticles on Macrophages. Environ. Sci.: Nano 2020, 7, 2032-2046, doi:10.1039/C9EN01329F. 
57. Vandendriessche, S.; Cambier, S.; Proost, P.; Marques, P.E. Complement Receptors and Their Role in Leukocyte Recruitment and Phagocytosis. Front. Cell Dev. Biol. 2021, 9, 624025, doi:10.3389/fcell.2021.624025.

58. Han, C.; Jin, J.; Xu, S.; Liu, H.; Li, N.; Cao, X. Integrin CD11b Negatively Regulates TLR-Triggered Inflammatory Responses by Activating Syk and Promoting Degradation of MyD88 and TRIF via Cbl-b. Nat Immunol 2010, 11, 734-742, doi:10.1038/ni.1908.

59. Ehirchiou, D.; Xiong, Y.; Xu, G.; Chen, W.; Shi, Y.; Zhang, L. CD11b Facilitates the Development of Peripheral Tolerance by Suppressing Th17 Differentiation. Journal of Experimental Medicine 2007, 204, 1519-1524, doi:10.1084/jem.20062292.

60. Varga, G.; Balkow, S.; Wild, M.K.; Stadtbaeumer, A.; Krummen, M.; Rothoeft, T.; Higuchi, T.; Beissert, S.; Wethmar, K.; Scharffetter-Kochanek, K.; et al. Active MAC-1 (CD11b/CD18) on DCs Inhibits Full T-Cell Activation. Blood 2007, 109, 661-669, doi:10.1182/blood-2005-12-023044.

61. Zhang, Q.; Lee, W.-B.; Kang, J.-S.; Kim, L.K.; Kim, Y.-J. Integrin CD11b Negatively Regulates Mincle-Induced Signaling via the Lyn-SIRPa-SHP1 Complex. Exp Mol Med 2018, 50, e439, doi:10.1038/emm.2017.256.

62. Schmid, M.C.; Khan, S.Q.; Kaneda, M.M.; Pathria, P.; Shepard, R.; Louis, T.L.; Anand, S.; Woo, G.; Leem, C.; Faridi, M.H.; et al. Integrin CD11b Activation Drives Anti-Tumor Innate Immunity. Nat Commun 2018, 9, 5379, doi:10.1038/s41467-018-07387-4.

63. Díez-Tercero, L.; Delgado, L.M.; Bosch-Rué, E.; Perez, R.A. Evaluation of the Immunomodulatory Effects of Cobalt, Copper and Magnesium Ions in a pro Inflammatory Environment. Sci Rep 2021, 11, 11707, doi:10.1038/s41598-021-91070-0. 